Proceedings of the Prehistoric Society 85, 2019, pp. 193-222 @ The Prehistoric Society. This is an Open Access article, distributed under the terms of the Creative Commons Attribution licence (http://creativecommons.org/ licenses/by/4.0/), which permits unrestricted re-use, distribution, and reproduction in any medium, provided the original work is properly cited.

doi:10.1017/ppr.2019.12

\title{
Neolithic Farming and Wild Plant Exploitation in Western Britain: Archaeobotanical and Crop Stable Isotope Evidence from Wales (c. 4000-2200 cal BC)
}

\author{
By EDWARD R. TREASURE ${ }^{1}$, DARREN R. GRÖCKE ${ }^{2}$, ASTRID E. CASELDINE ${ }^{3}$ and MIKE J. CHURCH ${ }^{1}$
}

The introduction of agriculture is a key defining element of the Neolithic, yet considerable debate persists concerning the nature and significance of early farming practices in north-west Europe. This paper reviews archaeobotanical evidence from 95 Neolithic sites (c. 4000-2200 cal BC) in Wales, focusing on wild plant exploitation, the range of crops present, and the significance of cereals in subsistence practices. Cereal cultivation practices in Early Neolithic Wales are also examined using cereal grain stable carbon $\left(\delta^{13} C\right)$ and nitrogen $\left(\delta^{15} N\right)$ isotope analysis. The Early Neolithic period witnessed the widespread uptake of cereals alongside considerable evidence for continued wild plant exploitation, notably hazelnuts and wild fruits. The possibility that wild plants and woodlands were deliberately managed or altered to promote the growth of certain plants is outlined. Small cereal grain assemblages, with little evidence for chaff and weed seeds, are common in the Early Neolithic, whereas cereal-rich sites are rare. Emmer wheat was the dominant crop in the Early Neolithic, while other cereal types were recorded in small quantities. Cereal nitrogen isotope $\left(\delta^{15} N\right)$ values from Early Neolithic sites provided little evidence for intensive manuring. We suggest that cultivation conditions may have been less intensive when compared to other areas of Britain and Europe. In the later Neolithic period, there is evidence for a decline in the importance of cereals. Finally, the archaeobotanical and crop isotope data from this study are considered within a wider European context.

Keywords: Neolithic, agriculture, archaeobotany, cereals, wild plants, crops, carbon isotopes, nitrogen isotopes, Wales

The dynamics of the Mesolithic-Neolithic transition in Britain and Ireland have been intensively researched for many years and it continues to remain a contentious area of debate. In particular, as the introduction of agriculture is a key defining element of the Neolithic, the nature and significance of early farming has been a major focus of research (Bickle \& Whittle 2014; Rowley-Conwy \& Legge 2015). Despite this, there

\footnotetext{
${ }^{1}$ Department of Archaeology, Durham University, South Road, DH1 3LE, Durham, County Durham, UK. Emails: e.r.treasure2@durham.ac.uk; m.j.church@durham.ac.uk ${ }^{2}$ Department of Earth Sciences, Durham University, South Road, DH1 3LE, Durham, County Durham, UK. Email: d.r.grocke@durham.ac.uk

${ }^{3}$ University of Wales Trinity Saint David, Faculty of Humanities \& Performing Arts, College St, Lampeter, SA48 7ED, Ceredigion, UK. Email: a.caseldine@uwtsd.ac.uk
}

remains little consensus on the speed of the transition from hunter-gathering to agriculture and the importance of arable agriculture in subsistence practices (Thomas 2014, 392; Rowley-Conwy \& Legge 2015). Traditionally, these debates have revolved around whether the Neolithic was characterised by an abrupt shift to an intensive mixed farming regime, potentially associated with considerable immigration, or whether it was a more gradual process with emphasis placed on indigenous hunter-gatherers in adopting and diffusing selected aspects of agriculture (eg, Thomas 2004; 2007; 2014; Rowley-Conwy 2004; 2011; Sheridan 2007; 2010; Whittle et al. 2011; Rowley-Conwy \& Legge 2015). In view of these debates, archaeobotanical research therefore has a key role in examining the nature and significance of Neolithic farming practices. 
The introduction of cereals into Britain (c. 3950$3850 \mathrm{cal} \mathrm{BC}$ ) and Ireland (c. $3750 \mathrm{cal} \mathrm{BC})$ appears to have been a rapid and widespread process (Stevens $\&$ Fuller 2012; Whitehouse et al. 2014). This does not provide evidence for migration per se, but rather it is more consistent with models favouring colonisation by farming communities at the onset of the Neolithic (eg, Rowley-Conwy 2004; 2011; Sheridan 2010; Stevens \& Fuller 2012; McLaughlin et al. 2016; Brace et al. 2019). However, a balance between migration and acculturation by indigenous hunter-gatherers should not be overlooked (eg, Whittle et al. 2011; Thomas 2014). For instance, the presence of cereals at a site does not necessarily indicate local cultivation and, in some instances, this may instead reflect the exchange of cereals (cf. Hillman 1982; Deforce et al. 2013; Meylemans et al. 2018). It is also evident that wild plant exploitation remained a significant component of subsistence practices (eg, Pelling \& Campbell 2013). Increasingly, it is recognised that wild plants were systematically and intensively exploited, possibly involving the deliberate management of woodlands/ wild plants (Colledge \& Conolly 2014; Bishop et al. 2015), blurring the traditional dichotomy between 'hunter-gathering' and 'farming' (Rowley-Conwy \& Layton 2011).

Whilst considerable research has examined the introduction of cereals, this has 'overshadowed' our understanding of the nature of farming regimes (Jones 2005). It is unclear whether the introduction of cereals was part of an integrated 'package' characterised by an intensive mixed farming regime, with crop and animal husbandry closely integrated, as observed in south-east and central Europe (Bogaard 2005; Halstead 2006). Alternatively, it has been suggested that cereal cultivation may have been 'episodic or short-lived' (Thomas 2003, 71). Understanding the nature of farming regimes has wider implications for how we understand the integration between animal and crop husbandry, the relative dietary importance of crops and animals, the organisation of household labour, and the ecological impact of farming (Bogaard 2004). Recent research using weed ecology and cereal carbon $\left(\delta^{13} \mathrm{C}\right)$ and nitrogen $\left(\delta^{15} \mathrm{~N}\right)$ isotope analysis provides significant potential to investigate the nature of farming regimes (Bogaard 2014).

The introduction of cereals was probably a complex process, potentially involving numerous (re-) introductions and failed introductions (cf. Boivin et al. 2012). However, less research has examined long-term trends in the importance of cereals, especially during the later Neolithic period (Whitehouse \& Kirleis 2014; McClatchie et al. 2016). Stevens and Fuller (2012) have drawn attention to evidence for a significant decline, or even an abandonment, of cereal cultivation in later Neolithic Britain. This large-scale narrative may, however, obscure subtle and important regional diversity in the importance of cereals (Bishop 2015; Worley et al. 2019). Therefore, the importance of regional approaches is increasingly being recognised (cf. Bell 2007a, 17; Bishop 2015; Griffiths 2018).

This paper focuses on the introduction of agriculture into Wales, a predominantly mountainous area in western Britain. Situated at the intersection between several regions, notably the Irish Sea Zone to the west and mainland Britain to the east, Wales represents an important area for understanding the onset and diffusion of the Neolithic (eg, Lynch 2000; Sheridan 2007; 2010; McLaughlin et al. 2016; Garrow et al. 2017). However, Neolithic farming practices in Wales have received very little attention and there has been an over-reliance on evidence from a handful of wellknown sites. Recently, the quantity of archaeobotanical research undertaken on Neolithic sites in Wales has significantly increased, largely due to developer-funded archaeology. This can be contrasted with well-studied areas such as southern England (Pelling \& Campbell 2013), Ireland (McClatchie et al. 2014; 2016), and Scotland (Bishop et al. 2009; Bishop 2015), as well as continental Europe (eg, Colledge \& Conolly 2007; Salavert 2011; Kirleis et al. 2012; Kirleis \& Fischer 2014; Sørensen \& Karg 2014).

We review the archaeobotanical evidence from 95 Neolithic sites, focusing on wild plant use, the introduction and significance of cereals, the nature of cereal cultivation practices, and evidence for a later Neolithic cereal decline. A pilot study using stable carbon $\left(\delta^{13} \mathrm{C}\right)$ and nitrogen $\left(\delta^{15} \mathrm{~N}\right)$ isotope analysis of Early Neolithic cereal grains was undertaken to provide new information on cultivation practices. The archaeobotanical and cereal isotope evidence is then considered in a regional and European research context.

\section{ENVIRONMENTAL AND ARCHAEOLOGICAL CONTEXT: NEOLITHIC WALES}

Recent developer-funded projects and research excavations undertaken across Wales have led to the discovery of important Neolithic sites. Consequently, a brief overview of the current state of research is 


\section{E.R. Treasure et al. NEOLITHIC FARMING \& WILD PLANT EXPLOITATION, WALES}

TABLE 1: CHRONOLOGICAL PERIODS FOR NEOLITHIC BRITAIN USED IN THIS PAPER

\begin{tabular}{lc}
\hline Period & Date range cal BC \\
\hline Early Neolithic & $4000-3400$ \\
Middle Neolithic & $3400-3000$ \\
Late Neolithic & $3000-2500$ \\
Beaker period & $2500-2200$ \\
\hline
\end{tabular}

There is no defined period name for 2500$2200 \mathrm{cal} \mathrm{BC}$, so the term Beaker period used here is interchangeable with 'Chalcolithic'

necessary. Table 1 presents the chronological periods used in this study.

Though dating evidence is patchy, the MesolithicNeolithic transition can be dated to within the centuries either side of $c .3700 \mathrm{cal} \mathrm{BC}$ in south Wales and the Marches, and probably also in north Wales (Whittle et al. 2011). However, recent evidence from Dorstone Hill, Herefordshire, in the Welsh Marches, suggests a slightly earlier date for the Early Neolithic (Ray \& Thomas 2018). Sea-routes in this area of western Britain are recognised as an 'important corridor of interaction' and the archaeological record reflects this (eg, Lynch 2000; Thomas 2003; Cummings \& Whittle 2004; Sheridan 2007; 2010; McLaughlin et al. 2016; Garrow et al. 2017, 103). Notably, similarities exist between west Wales and the wider Irish Sea Zone, whereas eastern areas of Wales are more comparable to mainland Britain (eg, Lynch 2000; Cummings \& Whittle 2004). It is important to consider this regional diversity when analysing the introduction of cereals. Recent interpretations emphasise a combination of both indigenous adoption and migration in the Neolithic transition and strontium isotope analysis of human remains from south-east Wales hint at migration in the earliest phases (Neil et al. 2017).

The Early Neolithic period is characterised by a significant change in the archaeological record (Burrow 2003). Various monumental and funerary sites including cursus monuments, megalithic tombs and causewayed enclosures were constructed during this period (Schulting \& Whittle 2003; Jones 2009; 2012; Davis \& Sharples 2017), though few have been recently and extensively excavated (Burrow 2003). Recent excavations confirm the presence of causewayed enclosures at Womaston in central Wales, Caerau in south-east Wales, and Banc Du in southwest Wales (Davis \& Sharples 2017). However, archaeobotanical evidence has only been published from Womaston at present (Jones 2009).

Early Neolithic occupation sites primarily comprise surface finds and ephemeral traces of activity, notably pits/pit groups (Kenney 2008). Pits/pit groups are characteristic site-types defined by small, shallow groups of charcoal-rich pits often containing pottery, which have been interpreted as containing occupation debris and, in some cases, structured deposits (AndersonWhymark \& Thomas 2012). Evidence for rectangular structures/houses has considerably increased in recent years with several examples now known and this can be compared with the more extensive evidence for these structures in Ireland (eg, Britnell 1984; Kenney 2008; Kenney et al. 2011; Barber \& Hart 2014; Smyth 2014; Rees \& Jones 2015). In terms of land use, the degree of mobility in settlement patterns is debated, though it appears that some sites were not occupied permanently (Neil et al. 2016).

Pollen studies have recorded relatively little evidence for substantial human impact on environments in the Early Neolithic, despite widespread archaeological evidence for activity (eg, Chambers 1982; Mighall \& Chambers 1995; Caseldine 2000; 2014; Innes et al. 2006; Walker et al. 2006; Fyfe 2007; Watkins et al. 2007; Grant 2008; Woodbridge et al. 2012; Brown 2013; Murphy et al. 2015; Caseldine et al. 2016; 2017). Small-scale, temporary clearances, occasionally associated with cereal-type pollen, are recorded, however, these do not appear to differ significantly in character from vegetation disturbances witnessed in the preceding Mesolithic (Bell 2007b, 340). The elm decline is a key feature of pollen records spanning this period. This decline is now attributed to a multi-causal model which emphasises the impact of both natural and anthropogenic factors (Parker et al. 2002; Innes et al. 2006; Batchelor et al. 2014). Evidence for Early Neolithic activity may be overlooked or underrepresented in regional pollen studies since woodland clearings may have been too small to detect (Whitehouse \& Smith 2010; Bell \& Noble 2012) and due to the poor dispersal of cereal pollen (Hall 1989). In addition, many pollen sequences are from upland zones and coastal wetlands, whereas there is more substantial evidence for Early Neolithic activity in lowland, inland areas (Fig. 1: Bell 2007a, 17).

For the later Neolithic period (Middle-Late Neolithic, c. 3400-2500 cal BC) and Beaker period (c. 2500-2000 cal BC), pits/pit groups represent typical evidence for 'occupation' whilst evidence for structures is rare 


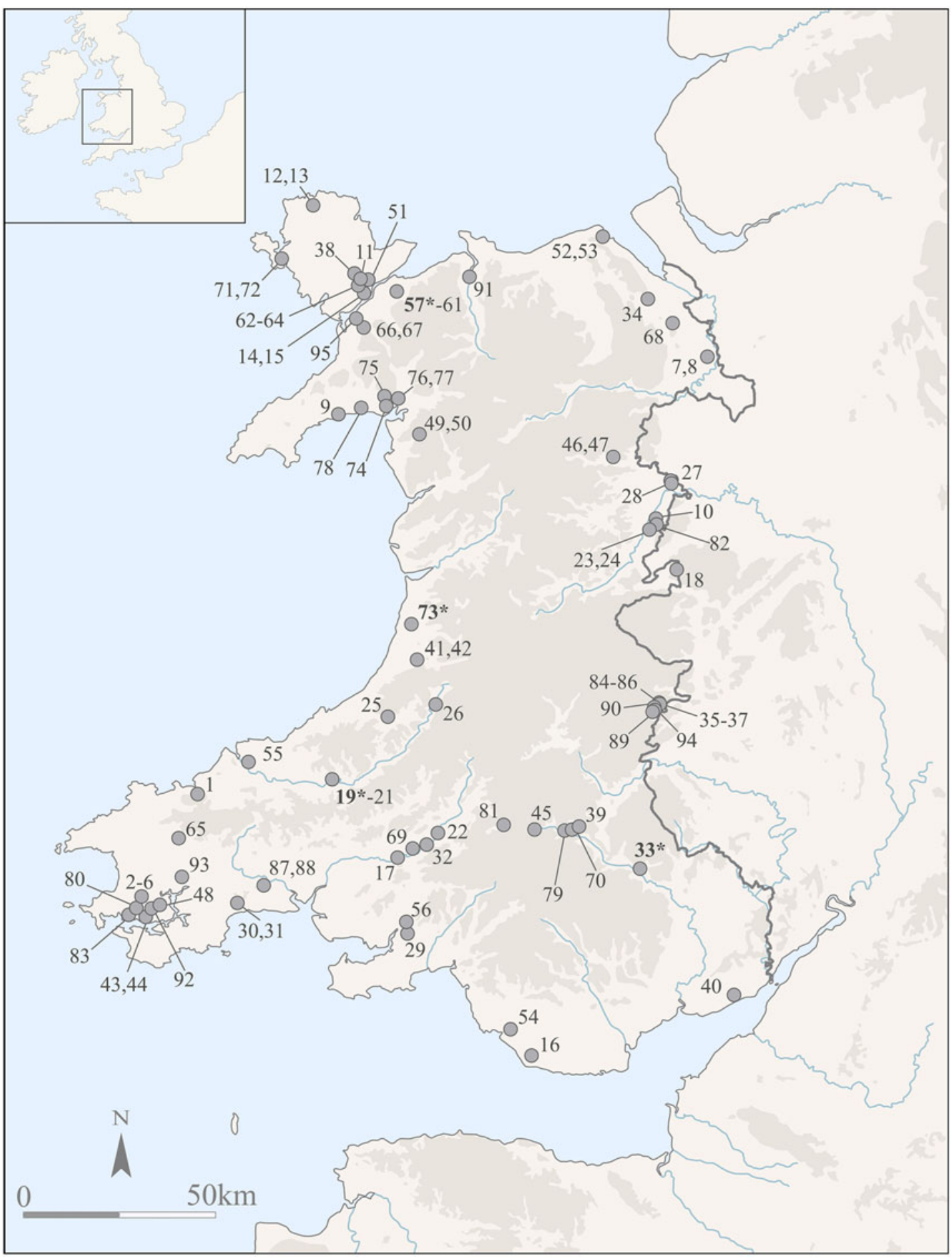

Fig. 1.

Distribution of sites with archaeobotanical evidence. Site numbers are presented in Table S1. Cereal grains were sampled for stable isotope analysis at sites denoted with a ${ }^{\text {‘' }}$ in bold 


\section{E.R. Treasure et al. NEOLITHIC FARMING \& WILD PLANT EXPLOITATION, WALES}

(eg, Britnell 1982; Gibson 1999; Kenney 2008). It is suggested that communities were (semi-)mobile (Peterson 2004; Halsted 2007). The Late Neolithic to Beaker period is characterised by the construction of numerous monuments, including henges, ring-ditches, and major palisaded enclosures (eg, Britnell \& Jones 2012; Barber \& Hart 2015; Jones \& Gibson 2017). Extensive evidence for activity in this period comes from burnt mounds, though the function of these sites is debated and their relationship to settlement activity is unclear (Halsted 2007, 174; Kenney 2012; Hart et al. 2014; Brown et al. 2016). Pollen studies for the Middle-Late Neolithic suggest an increase in woodland regeneration in some areas, followed by increasing impact which broadly begins in the Beaker period/ Early Bronze Age, extending to the later Bronze Age (eg, Chambers \& Price 1988; Mighall \& Chambers 1995; Nayling \& Caseldine 1997; Watkins et al. 2007; Brown 2013; Caseldine 2014; Caseldine et al. 2017).

\section{RECONSTRUCTING CEREAL CULTIVATION PRACTICES THROUGH STABLE CARBON $\left(\delta^{13} \mathrm{C}\right)$ AND NITROGEN $\left(\delta^{15} \mathrm{~N}\right)$ ISOTOPE ANALYSIS}

Archaeobotanical weed data can be used to investigate cultivation practices, however, a key challenge is the rarity of weed seeds in Neolithic archaeobotanical assemblages, particularly in Britain (Bogaard 2014; Stevens \& Fuller 2018). Stable carbon $\left(\delta^{13} C\right)$ and nitrogen $\left(\delta^{15} \mathrm{~N}\right)$ isotope analysis of cereals provides a method for directly investigating cultivation practices, especially manuring (Bogaard 2014).

Manuring can significantly elevate soil $\delta^{15} \mathrm{~N}$ values and cereal $\delta^{15} \mathrm{~N}$ values largely reflect the soil in which they are cultivated, as opposed to pulse crops which assimilate atmospheric nitrogen via $\mathrm{N}_{2}$-fixation (Fraser et al. 2011; Treasure et al. 2016). Bogaard et al. (2013) define three different levels of manuring intensity based on cereal $\delta^{15} \mathrm{~N}$ values: 'none or low' $\left(<3 \%\right.$ o $\left.\delta^{15} \mathrm{~N}\right)$, 'medium' (3-6\% $\left.\delta^{15} \mathrm{~N}\right)$ and 'high' ( $>6 \%$ o $\left.\delta^{15} \mathrm{~N}\right)$. 'High' cereal $\delta^{15} \mathrm{~N}$ values $(>6 \%$ o) are thought to reflect longterm, intensive manuring since short-term manuring (ie, 1-2 years) may not significantly impact cereal $\delta^{15} \mathrm{~N}$ values (Fraser et al. 2011). Other potential causes of ${ }^{15} \mathrm{~N}$-enrichment require further research, such as environmental factors (ie, waterlogging), use of other manure/soil-amendments (ie, human faeces, middening), vegetation burning, and variation in baseline Neolithic soil $\delta^{15} \mathrm{~N}$ values (cf. Szpak 2014). A baseline $\delta^{15} \mathrm{~N}$ value for Neolithic soil can be estimated by analysing the $\delta^{15} \mathrm{~N}$ values of wild herbivores recovered from the same site/ period (Gron et al. 2017; Aguilera et al. 2017; Styring et al. 2017). Wild herbivore $\delta^{15} \mathrm{~N}$ values are not available for the sites analysed in Early Neolithic Wales. However, for Neolithic sites in southern Britain, an average $\delta^{15} \mathrm{~N}$ value for deer bone collagen of 5.2\% has been recorded (Stevens et al. 2012) and using a trophic-level enrichment of 3-5\% (Bocherens \& Drucker 2003) places the $\delta^{15} \mathrm{~N}$ values for Neolithic soils at c. $0-2 \%$ (ie, low/no manuring range). Cereal $\delta^{13} \mathrm{C}$ values reflect atmospheric $\mathrm{CO}^{2}$ assimilation and water availability in the soil and this can be used alongside cereal $\delta^{15} \mathrm{~N}$ values to investigate cultivation practices, soil conditions and environmental factors (Fiorentino et al. 2015).

The impact of charring and contamination is an important consideration in the application of $\delta^{13} \mathrm{C}$ and $\delta^{15} \mathrm{~N}$ analysis to archaeological charred cereal grains. Low temperature charring, which produces morphologically well-preserved and minimally distorted cereal grains, has a small impact on cereal $\delta^{13} \mathrm{C}$ values (up to $+0.2 \%$ ) and $\delta^{15} \mathrm{~N}$ values (up to $+0.6 \%$; Nitsch et al. 2014). Contamination and pre-treatment methods can cause small variations in cereal $\delta^{13} \mathrm{C}$ and $\delta^{15} \mathrm{~N}$ values, though various studies have reported no consistent and significant differences between pre-treated and non-treated samples (Lightfoot \& Stevens 2012; Styring et al. 2016; Aguilera et al. 2017; Brinkkemper et al. 2018).

\section{ARCHAEOBOTANICAL REVIEW METHODOLOGY}

Archaeobotanical data was collated from published and unpublished sources. Contextual information was recorded for each site (region, location, period, dating evidence, site-type, feature/context type, date excavated/published, references). Plant remains were recovered by bulk sampling and flotation. The majority of archaeobotanical data derives from sites where full site/excavation reports are available and where full analysis of archaeobotanical data has been undertaken. For a small number of sites, the archaeobotanical evidence derives from the 'assessment' stage as this is the only work undertaken to date. 'Assessments' typically comprise the quick review of all the samples within an assemblage to assess their nature, significance and potential. This can provide valuable information about the nature of an archaeobotanical assemblage (eg, the presence/absence of cereal-rich contexts). The full dataset is presented in Supplementary Data 
Tables S1 and S2 and site locations are plotted in Figure 1.

The integrity of archaeobotanical samples from Neolithic sites needs to be closely examined to account for issues of contamination (Stevens \& Fuller 2012; 2015; Bishop 2015; Pelling et al. 2015). An extreme option would be to only include samples with directly-dated plant remains (eg, Stevens \& Fuller 2012), however, such an approach would result in a very small dataset. To account for this issue, a distinction was made between sites with archaeobotanical data classified as having either secure or good dating evidence and sites where archaeobotanical data is moderately well-dated, though it can still be assigned to a specific period. Full details of this site-selection methodology are provided in Table S1. Samples which were undated, poorly phased, or contaminated are excluded and consequently the archaeobotanical data may differ slightly from that in the original reports.

Table S2 summarises the archaeobotanical data (preservation type, samples, quantity of plant remains). To standardise the dataset, three cereal grain fragments were recorded as one cereal grain and spikelet forks were recorded as two chaff fragments. To provide information on cereal cultivation conditions/ practices, potential arable weeds were recorded on a context-by-context basis for contexts containing $\geq 10$ cereal remains (grain, chaff; cf. Bogaard \& Jones 2007, 367). Nomenclature follows Stace (2010).

CEREAL GRAIN STABLE CARBON $\left(\delta^{13} \mathrm{C}\right)$ AND NITROGEN $\left(\delta^{15} \mathrm{~N}\right)$ ISOTOPE ANALYSIS METHODOLOGY

Stable carbon $\left(\delta^{13} \mathrm{C}\right)$ and nitrogen $\left(\delta^{15} \mathrm{~N}\right)$ isotope analysis was undertaken on 51 charred cereal grains (emmer wheat \& barley) from four Early Neolithic sites: Plas Gogerddan (Site 73: Caseldine 1992), Gwernvale (Site 33: Caseldine in prep.), Parc Bryn Cegin (Site 57: Schmidl et al. 2008), and Cwm Meudwy (Site 19: Caseldine \& Griffiths 2006). See Table 2 and Table S4 for full details of the sites.

Following the methodological justification outlined by Gron et al. (2017), each sample is an individual cereal grain, opposed to bulk samples of $>10$ grains (eg, Bogaard et al. 2013). Each cereal grain was measured, and the degree of preservation/distortion noted, following Hubbard and al-Azm (1990). Most grains were well-preserved (80\%: P2/P3) with little distortion (80\%: D2). Changes in cereal $\delta^{13} \mathrm{C}$ and $\delta^{15} \mathrm{~N}$ values introduced by charring are therefore likely to be small.
TABLE 2: CEREAL GRAIN SAMPLES FROM EARLY NEOLITHIC SITES

\begin{tabular}{|c|c|c|c|}
\hline Site & $\begin{array}{l}\text { Emmer } \\
\text { wheat } \\
\text { samples }\end{array}$ & $\begin{array}{c}\text { Barley } \\
\text { samples }\end{array}$ & Site type \\
\hline $\begin{array}{l}\text { Plas Gogerddan } \\
\text { (Site 73) }\end{array}$ & 26 & 2 & $\begin{array}{l}\text { Small, isolated } \\
\text { pit }\end{array}$ \\
\hline $\begin{array}{l}\text { Cwm Meudwy (1) } \\
\text { (Site 19) }\end{array}$ & 6 & 1 & Pit group \\
\hline Gwernvale (Site 33) & 6 & 2 & $\begin{array}{l}\text { Midden \& } \\
\text { rectangular } \\
\text { structure/house }\end{array}$ \\
\hline $\begin{array}{l}\text { Parc Bryn Cegin (1) } \\
\quad \text { (Site 57) }\end{array}$ & 7 & 1 & $\begin{array}{l}\text { Rectangular } \\
\text { structure/house }\end{array}$ \\
\hline
\end{tabular}

No offset has been applied to cereal $\delta^{13} \mathrm{C}$ and $\delta^{15} \mathrm{~N}$ values to account for charring due to potentially wide and unknown variation in charring conditions and potential variability in $\delta^{13} \mathrm{C}$ and $\delta^{15} \mathrm{~N}$ in a single cereal plant/field. Adhering sediment on the grains was minimal/not present and this was removed by gentle scraping. Each grain was halved and homogenised in an agate pestle and mortar. Samples were not pre-treated to remove potential contaminants or screened for contamination using Fourier transform infrared spectroscopy (FTIR). Brinkkemper et al. (2018) indicate that reliable $\delta^{13} \mathrm{C}$ and $\delta^{15} \mathrm{~N}$ measurements of cereal grains can be obtained from untreated samples which are cleaned of visible adhering sediment, provided that grains are not heavily encrusted in sediment.

Stable isotope measurements, total organic carbon, and total nitrogen content of the samples were undertaken in the Stable Isotope Biogeochemistry Laboratory (SIBL) at Durham University using a Costech Elemental Analyser (ECS 4010) connected to a Thermo Scientific Delta V Advantage isotope ratio mass spectrometer. Carbon isotope ratios are corrected for ${ }^{17} \mathrm{O}$ contribution and reported in standard delta $(\delta)$ notation in per mil $(\%)$ relative to Vienna Pee Dee Belemnite (VPDB). Nitrogen isotope ratios are reported at atmospheric nitrogen (AIR). Isotopic accuracy was monitored through routine analyses of in-house standards (glutamic acid, $\delta^{13} \mathrm{C}=-11 \%$ o, $\delta^{15} \mathrm{~N}=-7.5 \%$; urea, $\delta^{13} \mathrm{C}=-43.3 \%$, $\delta^{15} \mathrm{~N}=-0.56 \%$; spar calcite, $\delta^{13} \mathrm{C}=2.9 \%$ ), which were stringently calibrated against international standards (eg, USGS40, USGS24, IAEA-600, IAEA-N-1, IAEA-N-2): this provided a linear range in $\delta^{13} \mathrm{C}$ between $-44 \%$ and $3 \%$ o and in $\delta^{15} \mathrm{~N}$ between $-7.5 \%$ and $20.4 \%$. Analytical variation in carbon and nitrogen isotope analyses 


\section{E.R. Treasure et al. NEOLITHIC FARMING \& WILD PLANT EXPLOITATION, WALES}

was typically $\pm 0.1 \%$ for replicate analysis of the international standards and typically $<0.2 \%$ on replicate sample analysis. Total organic carbon and nitrogen data was obtained as part of the isotopic analysis using an internal standard (glutamic acid, $40.82 \% \mathrm{C}$, $9.52 \% \mathrm{~N})$.

To compare cereal $\delta^{13} \mathrm{C}$ values from different chronological periods it is necessary to account for changes in the $\delta^{13} \mathrm{C}$ of atmospheric $\mathrm{CO}_{2}$ throughout the Holocene. The $\delta^{13} \mathrm{C}$ of atmospheric $\mathrm{CO}_{2}$ was estimated using the AIRCO2_LOESS system (Ferrio et al. 2005) and carbon isotope discrimination $\left(\Delta^{13} \mathrm{C}\right)$ independent of source $\mathrm{CO}_{2}$ was calculated following Farquhar et al. (1989).

\section{RESULTS}

Overview: site types, sampling and archaeobotanical data recorded

Archaeobotanical evidence was collated from 95 sites (Fig. 1), comprising 28 Early Neolithic, 18 Middle Neolithic, 22 Late Neolithic, and 27 Beaker period sites. Secure/very well-dated archaeobotanical assemblages were present at 50 sites and archaeobotanical assemblages with good/moderate dating evidence were present at a further 45 sites. The distribution of sites primarily reflects the location of developer-funded archaeological projects, particularly in southern areas and in the north-west. Most sites are in lowland areas, with some clustering around river valleys, whereas few sites are in the more mountainous central region. Charred plant remains are the most common form of evidence and waterlogged plant remains were recorded at one site: Llandevenny (Site 40: Brown 2007a). Pottery impressions of plant remains were present at one site: Ogmore-by-Sea (Site 54: Burrow 2003). Plant remains were absent (excluding wood charcoal) at 16 sites, despite bulk sampling and flotation.

A wide range of site-types have been sampled (Table 3). Pits/pit group sites were the most frequently sampled for all periods, whilst only a small number of structures/houses have been sampled for the Early Neolithic (four sites) and Late Neolithic (two sites). A larger quantity of data is available from funerary/ monumental sites and burnt mounds for the Late Neolithic and Beaker period. Where information was available, the number of samples analysed was typically small $(\leq 5)$ which primarily reflects the small number of Neolithic features excavated at many sites. More extensive sampling ( $>20$ samples) has only been undertaken
TABLE 3: SITE TYPES WITH ARCHAEOBOTANICAL EVIDENCE FOR EACH PERIOD

\begin{tabular}{|c|c|c|}
\hline Period & No sites & Site types \\
\hline Early Neolithic & 28 & $\begin{array}{l}20 \text { pits/pit groups, } 4 \\
\text { rectangular structures/houses } \\
\text { (inc. } 1 \text { midden), } 1 \text { ? } \\
\text { occupation layer, } 1 \\
\text { causewayed enclosure, } 1 \\
\text { cursus monument, } 1 \text { shell } \\
\text { midden }\end{array}$ \\
\hline Middle Neolithic & 18 & $\begin{array}{l}16 \text { pits/pit groups, } 1 \text { ? } \\
\text { occupation layer, } 1 \text { burnt } \\
\text { mound }\end{array}$ \\
\hline Late Neolithic & 22 & $\begin{array}{l}12 \text { pits/pit groups, } 2 \\
\text { structures/houses, } 2 \text { ? } \\
\text { occupation layers, } 1 \text { henge, } \\
1 \text { barrow, } 1 \text { timber circle, } 1 \\
\text { shell midden, } 2 \text { burnt } \\
\text { mounds }\end{array}$ \\
\hline Beaker period & 27 & $\begin{array}{l}9 \text { pits/pit groups, } 1 \text { ? } \\
\text { occupation layer, } 1 \text { henge, } \\
1 \text { barrow, } 3 \text { palisaded } \\
\text { enclosures, } 4 \text { ring-ditches, } 8 \\
\text { burnt mounds }\end{array}$ \\
\hline
\end{tabular}

Detailed descriptions of the sites and contexts are provided in Table S4

at four sites: Parc Bryn Cegin (1) (Site 57: Schmidl et al. 2008), Parc Bryn Cegin (2) (Site 58: Schmidl et al. 2008), Upper Ninepence (Site 84: Caseldine 1999), and Vaynor Henge (Site 88: Rackham 2015).

Figures 2 and 3 summarise the plant remains for each period by site type. Hazel nutshell (Corylus avellana L.) is the most frequently recorded plant remain and was present at 21 Early Neolithic sites, 17 Middle Neolithic, 15 Late Neolithic, and 15 Beaker period sites. Other wild fruits and nuts (excluding hazel nutshell) were less frequently recorded. For all periods, wild plant remains were present at a range of site types. Cereal grains were commonly recorded in the Early Neolithic (16 sites), though chaff was rarer (10 sites). Evidence for cereals in the Early Neolithic comes from pits/pit groups (11 sites), structures/ houses ( 3 sites), a causewayed enclosure ( 1 site) and one shell midden (1 site). For the Middle Neolithic, Late Neolithic, and Beaker periods, cereal grains and chaff are rarer and the evidence primarily derives from pits/pit groups. Evidence for other crops was very rare: Celtic bean (Vicia faba L.) was recorded at one Middle Neolithic site (pottery impression at Ogmore-by-Sea, Site 54: Burrow 2003) and one 


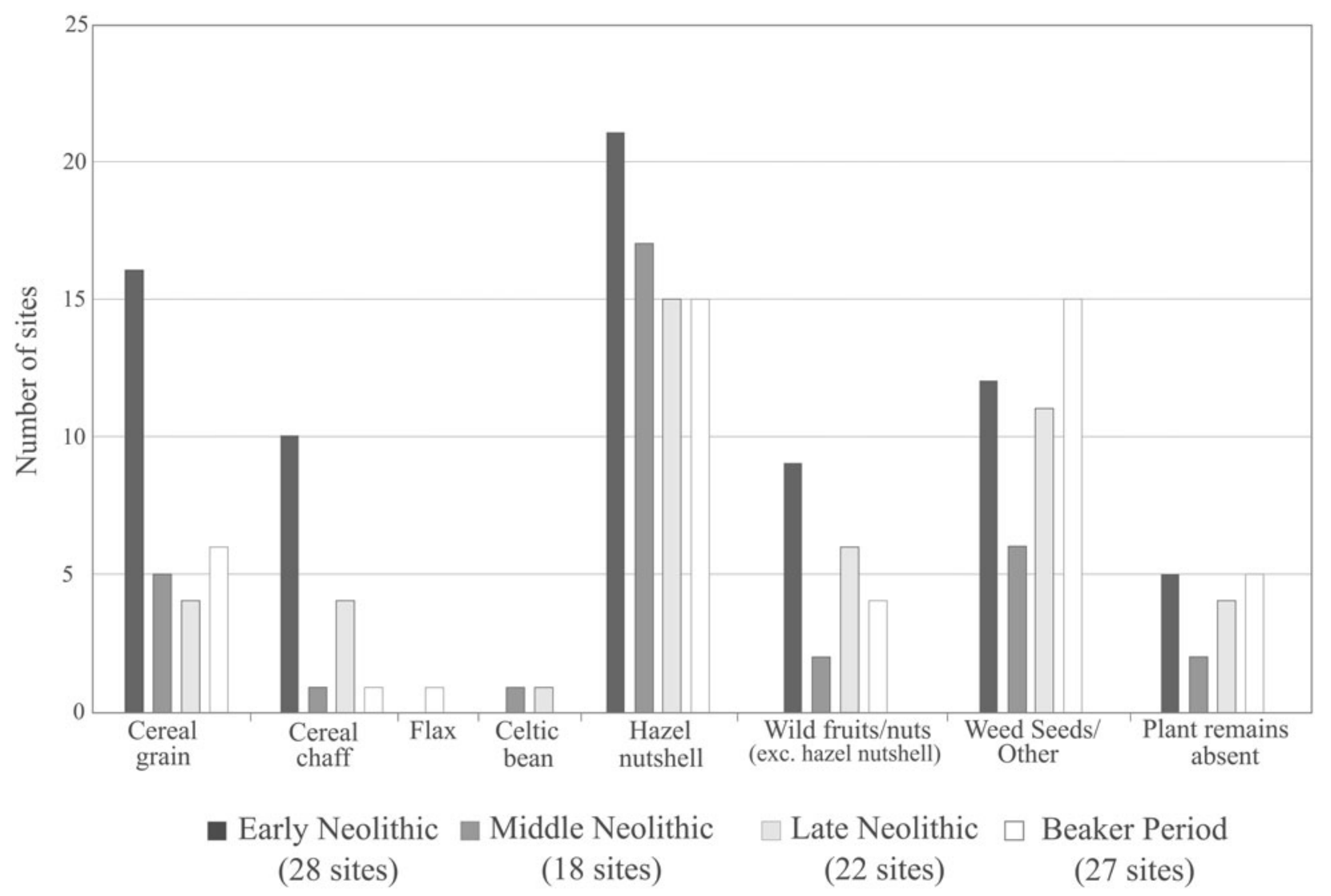

Fig. 2.

Summary of plant remains recorded

Late Neolithic site (Capel Eithin, Site 11: Williams 1999), whilst flax (Linum usitatissimum L.) was recorded at one Beaker period site (Buttington Cross, Site 10: Clapham 2009). Direct AMS ${ }^{14} \mathrm{C}$ dating has not been undertaken for the Celtic bean or flax remains. Weed seeds and other plant remains were commonly recorded, some of which may be arable weeds (see below).

\section{Wild plants recorded}

Hazel nutshell fragments were frequently recovered for all periods (Fig. 2), though the quantity and density of shell fragments varied significantly between different site types (see Table 4 for illustrative examples). In general, pits/pit groups sites typically produced high or very high densities of hazel nutshell. High densities of hazel nutshell were also present in the probable Early
Neolithic structure at Cwmifor (Site 22: Rackham 2014), though a low density of hazel nutshell was recorded at Parc Bryn Cegin (Site 57: Schmidl et al. 2008). Overall, hazel nutshell typically occurs in higher densities in 'occupation' sites (pits, structures) and in lower densities in other site types, notably funerary and monumental sites.

Evidence for other wild plant remains (fruits and nuts, excluding hazel nutshell) was rarer (Fig. 4) and was present at nine Early Neolithic sites, two Middle Neolithic sites, six Late Neolithic sites, and four Beaker period sites. The commonly recorded fruits were raspberry/ blackberry (Rubus idaeus L./R. fruticosus L. agg.) and crab apple (Malus sylvestris L. Mill.). Charred acorn (Quercus sp.) remains (cotyledons, nutshell fragments, cupules) have been recorded in small quantities at six sites (1 Early Neolithic, 1 Middle Neolithic, 2 Late Neolithic, and 2 Beaker period sites). Evidence for other 
E.R. Treasure et al. NEOLITHIC FARMING \& WILD PLANT EXPLOITATION, WALES
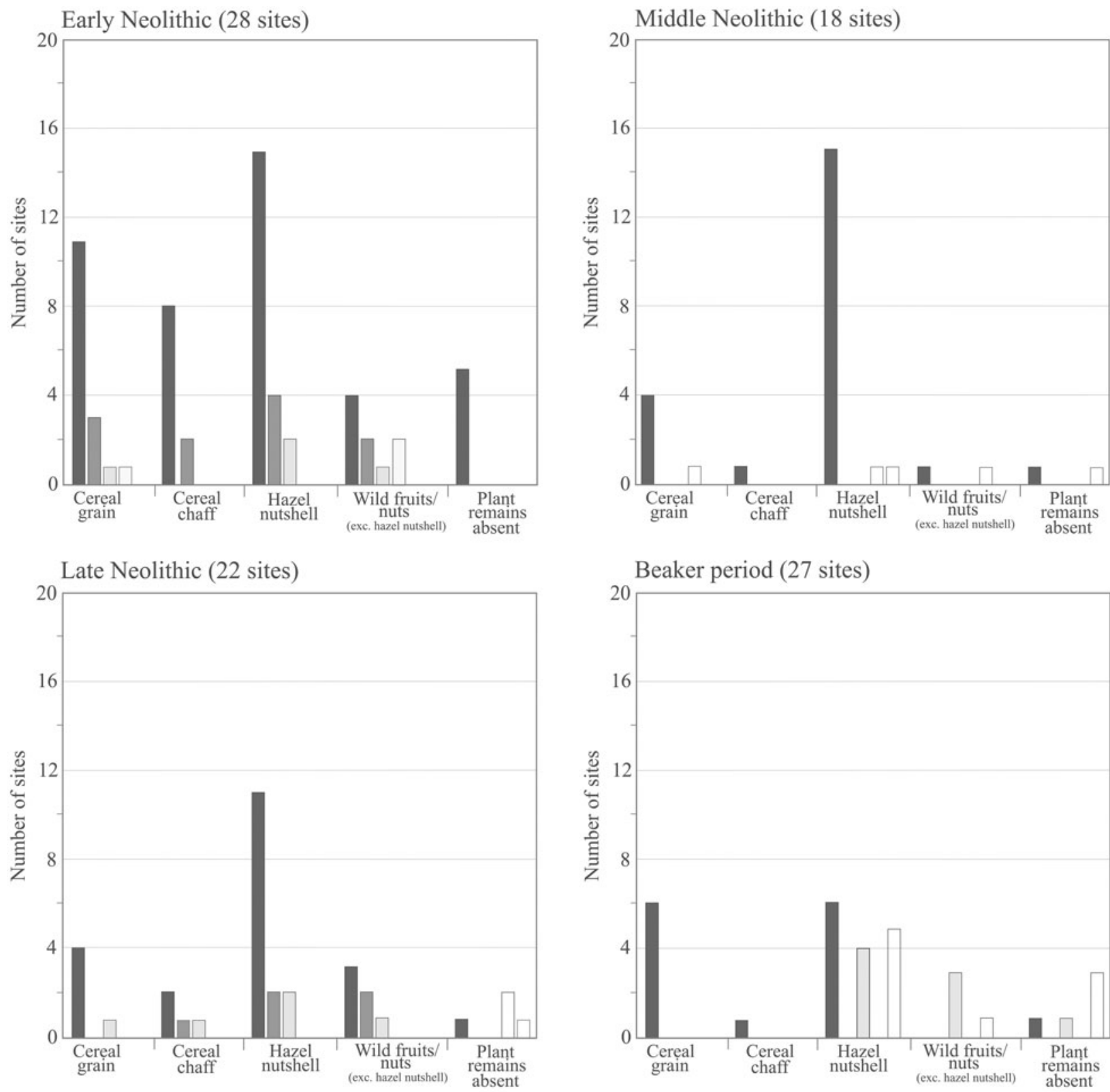

Pits/Pit Groups $\square$ Structures $\square$ Funerary/Monumental $\quad \square$ Other $\square$ Burnt mounds

Fig. 3.

Summary of plant remains recorded by site type. Number of sites (in parentheses) refers to the total number of sites for each period

wild fruits including hawthorn (Crataegus monogyna Jacq.), sloe (Prunus spinosa L.), and elder (Sambucus nigra L.) were only rarely recorded. Other plants recorded in the 'weed seed and other' category may also include deliberately gathered plants (Behre 2008), for instance, selfheal (Prunella vulgaris L.), black-bindweed (Fallopia convolvulus (L.) Á. Löve), and sheep's sorrel (Rumex acetosella L.). 
TABLE 4: SUMMARY OF HAZEL NUTSHELL DATA FROM SELECTED SITES WHERE INFORMATION ON THE SAMPLE VOLUME WAS AVAILABLE

\begin{tabular}{|c|c|c|c|}
\hline Site type & Site & $\begin{array}{l}\text { Hazel } \\
\text { nutshell } \\
\text { frags }\end{array}$ & $\begin{array}{c}\text { Density } \\
\text { hazel } \\
\text { nutshell } \\
\text { (frags/litre } \\
\text { soil) } \\
\end{array}$ \\
\hline \multirow{9}{*}{$\begin{array}{l}\text { Pits/pit } \\
\text { groups }\end{array}$} & $\begin{array}{l}\text { Early Neolithic } \\
\text { Lower Scoveton (1) } \\
\text { (Site } 43)\end{array}$ & 13 & $<1$ \\
\hline & Wiston (Site 93) & 479 & 11 \\
\hline & Llandefaelog (Site 39) & 1221 & 14 \\
\hline & $\begin{array}{l}\text { Pysgodlyn Farm } \\
\text { (Site 79) }\end{array}$ & 934 & 24 \\
\hline & $\begin{array}{l}\text { Plas Gogerddan } \\
\quad \text { (Site } 73 \text { ) }\end{array}$ & 117 & 29 \\
\hline & Pen-y-Crug (Site 70) & 15573 & 75 \\
\hline & $\begin{array}{l}\text { Gurrey Cottage } \\
\text { (Site 32) }\end{array}$ & 850 & 106 \\
\hline & $\begin{array}{l}\text { Middle Bastleford (1) } \\
\quad \text { (Site 48) }\end{array}$ & 7713 & 133 \\
\hline & $\begin{array}{l}\text { Gelli-Wern Isaf } \\
\quad \text { (Site 29) }\end{array}$ & 2047 & 409 \\
\hline \multirow[t]{2}{*}{$\begin{array}{c}\text { Rectangular } \\
\text { structures }\end{array}$} & $\begin{array}{l}\text { Parc Bryn Cegin (1) } \\
\quad(\text { Site 57) }\end{array}$ & 571 & 1 \\
\hline & Cwmifor (Site 22) & $>7000$ & 37 \\
\hline $\begin{array}{l}\text { Causewayed } \\
\text { enclosure }\end{array}$ & Womaston (Site 94) & 1 & $<1$ \\
\hline \multicolumn{4}{|c|}{ Middle Neolithic } \\
\hline \multirow[t]{2}{*}{$\begin{array}{l}\text { Pits/pit } \\
\text { groups }\end{array}$} & $\begin{array}{l}\text { Lower Scoveston (2) } \\
\quad \text { (Site 44) }\end{array}$ & 108 & 2 \\
\hline & $\begin{array}{l}\text { Pen-y-Banc (Site 69) } \\
\text { Late Neolithic }\end{array}$ & 418 & 7 \\
\hline \multirow{3}{*}{$\begin{array}{l}\text { Pits/pit } \\
\text { groups }\end{array}$} & Westfields (Site 92) & 1026 & 19 \\
\hline & Cilsan Mill (Site 17) & 189 & 63 \\
\hline & Steynton (Site 80) & 7456 & 104 \\
\hline $\begin{array}{l}\text { Burnt } \\
\text { mound }\end{array}$ & $\begin{array}{l}\text { Glan-rhŷd Bridge (1) } \\
\quad \text { (Site 30) }\end{array}$ & 48 & 1 \\
\hline Henge & $\begin{array}{l}\text { Beaker period } \\
\text { Vaynor Henge } \\
\text { (Site } 88)\end{array}$ & 42 & $<1$ \\
\hline $\begin{array}{l}\text { Palisaded } \\
\text { enclosure }\end{array}$ & $\begin{array}{l}\text { Hindwell Double } \\
\text { Palisaded Enclosure } \\
\text { (Site 36) }\end{array}$ & 1 & $<1$ \\
\hline $\begin{array}{l}\text { Burnt } \\
\text { mound }\end{array}$ & $\begin{array}{l}\text { Glan-rhŷd Bridge (2) } \\
\quad \text { (Site 31) }\end{array}$ & 11 & $<1$ \\
\hline
\end{tabular}

The density of hazel nutshell is expressed relative to litres of soil processed and displayed by site type

\section{Cereal types recorded}

Figure 5 summarises the relative occurrence of different cereal types at sites. For the Early Neolithic, emmer wheat (Triticum dicoccum L.) was the most frequent cereal type (recorded at 11/16 sites), whilst barley (Hordeum sp.) was recorded at 9/16 sites (both hulled and naked type were recorded). Oat (Avena sp.) and naked wheat (Triticum aestivum L./T. durum Desf./T. turgidum L.), are less frequently recorded in Early Neolithic sites. For Middle Neolithic sites, cereals recorded include barley and wheat (emmer wheat, indeterminate glume wheat (Triticum sp.), naked wheat). Similarly, for the Late Neolithic, barley (both hulled and naked types), wheat (emmer wheat, indeterminate glume wheat, naked wheat), and oat are recorded. For the Beaker period, barley (only hulled barley confirmed) and wheat (naked wheat) were recorded.

Figure 6 provides a comparison between the relative proportions of different cereal types for sites which produced $>10$ cereal remains (grains and chaff). This data was available for ten Early Neolithic and one Late Neolithic site. For the Early Neolithic period, wheat, most likely emmer, is the dominant cereal type and barley only forms a small proportion of most cereal assemblages. Naked wheat forms only a very small portion of cereal assemblages. For the Late Neolithic, data are only available from Capel Eithin (Site 11: Williams 1999). The cereal assemblage from this site differs from other Early Neolithic assemblages as it is dominated by barley, primarily naked barley, and there is minimal evidence for other cereal types including wheat (naked wheat, emmer) and oat. One sample which produced a rye grain (Secale cereale L.) and oat, including bristle oat (Avena strigosa Schreb.), is excluded since these remains are almost certainly intrusive.

\section{Quantity of cereal remains}

Information on the quantity of cereals (grains and chaff) was available for most sites and this is summarised in Figure 7 in relation to the number of samples analysed. Both grains and chaff occur in larger quantities in Early Neolithic sites, which typically produced small assemblages of cereal grains consisting of $\leq 50$ cereal grains ( $8 / 14$ sites), whilst chaff was significantly rarer and most sites $(8 / 10)$ produced $\leq 5$ chaff remains. For the Early Neolithic, 50-100 grains were recorded at three sites and $>100$ grains were recorded at three sites, whilst $>100$ chaff remains were recorded at one site. In comparison to the Early Neolithic, cereals (grains and chaff) occur in smaller quantities in the Middle Neolithic, Late Neolithic, and Beaker period. For instance, $\leq 20$ grains and chaff were recorded at 
E.R. Treasure et al. NEOLITHIC FARMING \& WILD PLANT EXPLOITATION, WALES

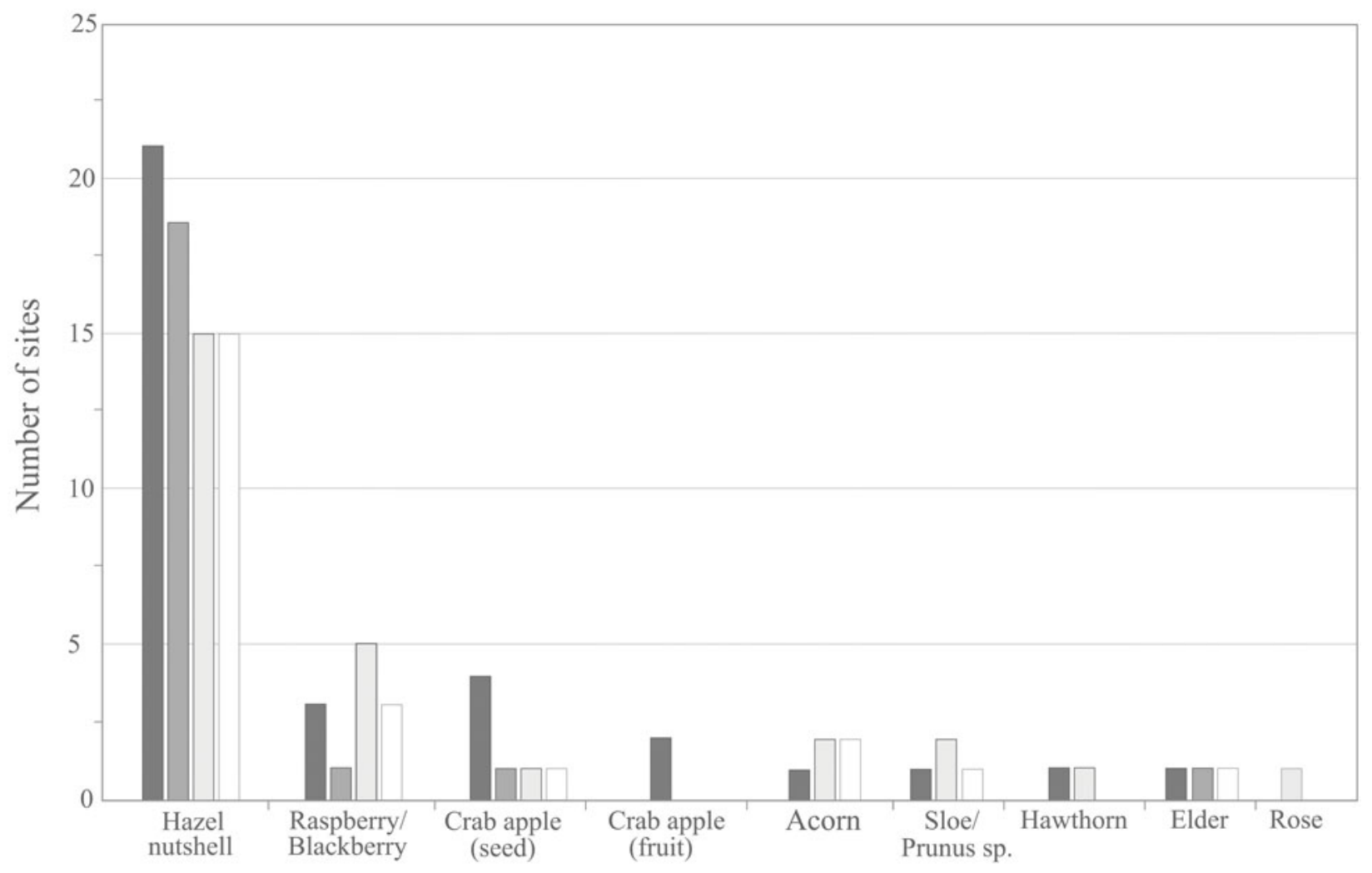

\section{Early Neolithic $\quad$ Middle Neolithic $\square$ Late Neolithic $\square$ Beaker Period (28 sites) (18 sites) (22 sites) \\ (27 sites)}

Fig. 4.

Wild plants recorded

all Middle Neolithic sites, most Late Neolithic sites, and all Beaker period sites. One Late Neolithic site, Capel Eithin (Site 11: Williams 1999), produced a large cereal assemblage (>100 grains).

Sampling strategies influenced the recovery of cereals. Grains and chaff occurred more frequently and in larger quantities at sites where larger numbers of samples were analysed. This is particularly apparent for the Early Neolithic period: larger assemblages of cereal grain and chaff were more frequently recorded at sites with $>5$ samples.

\section{Cereal-rich sites}

Large assemblages of cereals (>100 remains) were recorded at three Early and one Late Neolithic site. This data is summarised in Table 5. Large grain assemblages dating to the Early Neolithic have all been recovered from pits: Pen-y-Crug (Site 9: Rackham 2014), Cwmifor (Site 13: Rackham 2014), and Plas Gogerddan (Site 26: Caseldine 1992). At Cwmifor (Site 13: Rackham 2014), 75\% of the cereal grain assemblage (204 grains) was recovered from one pit (1/11 samples), whilst at Pen-y-Crug (Site 9: Rackham 2014), 90\% of the grains (513 grains) were recovered from two pits (2/8 samples). At both sites, emmer wheat was the dominant cereal type and chaff was rare. The pit at Plas Gogerddan (Site 26: Caseldine 1992) produced a rich assemblage of emmer wheat grains and chaff, occasional barley grains and one weed seed. ${ }^{1}$ The chaff primarily consisted of emmer wheat glume bases and spikelet forks, though rachis fragments and basal internodes were also 


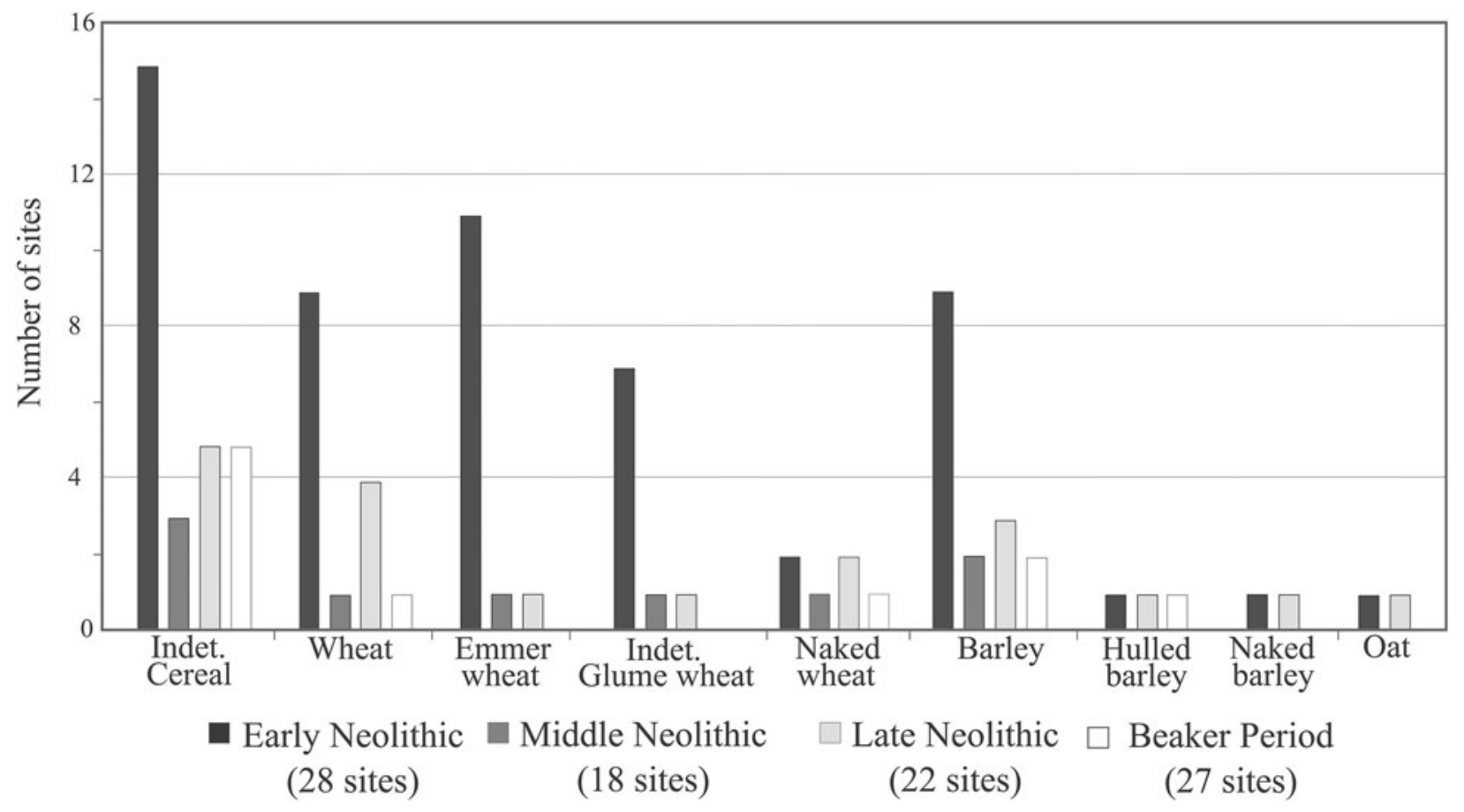

Fig. 5.

Cereal types recorded

Early Neolithic

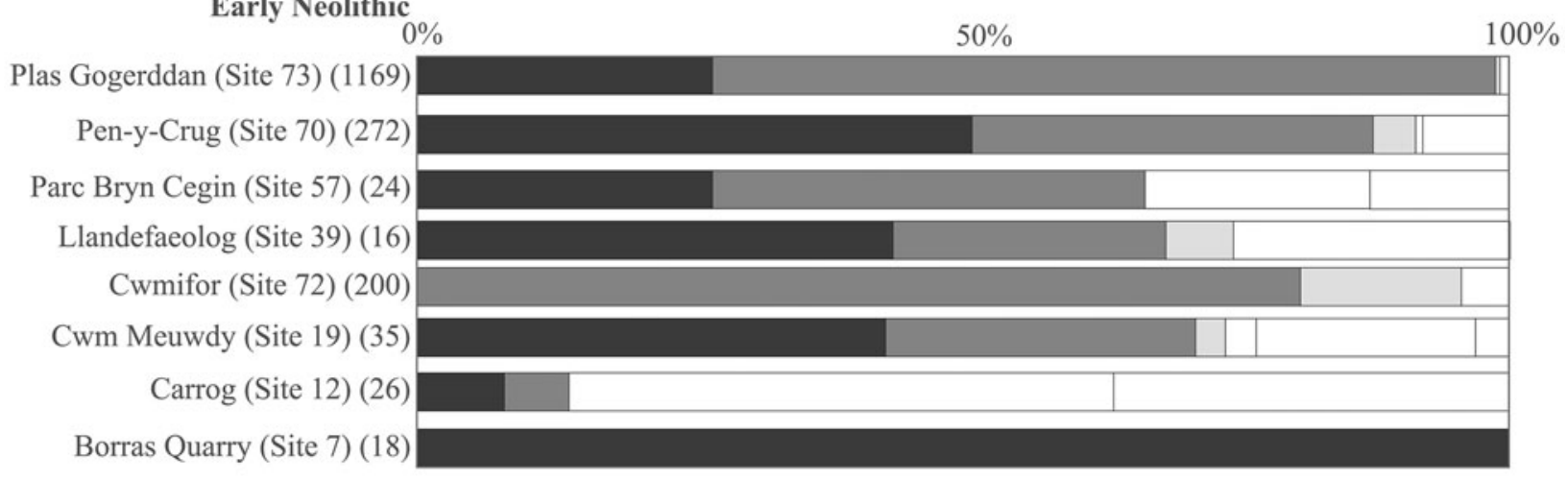

Middle Neolithic

Upper Ninepence (Site 84) (25)

Late Neolithic

Capel Eithin (Site 11) (329)

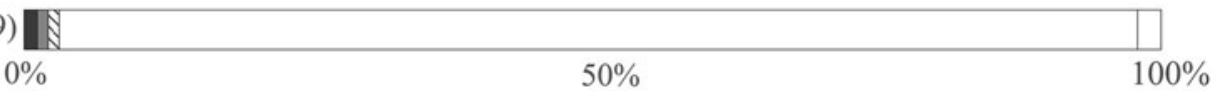

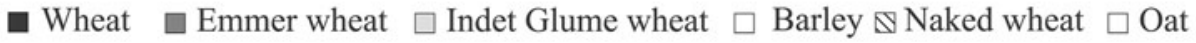

Fig. 6.

Proportions of different cereal types at sites where $>10$ identifiable cereals remains (grains, chaff) were present. The number in parentheses indicates the quantity of identifiable cereal remains recovered 
E.R. Treasure et al. NEOLITHIC FARMING \& WILD PLANT EXPLOITATION, WALES
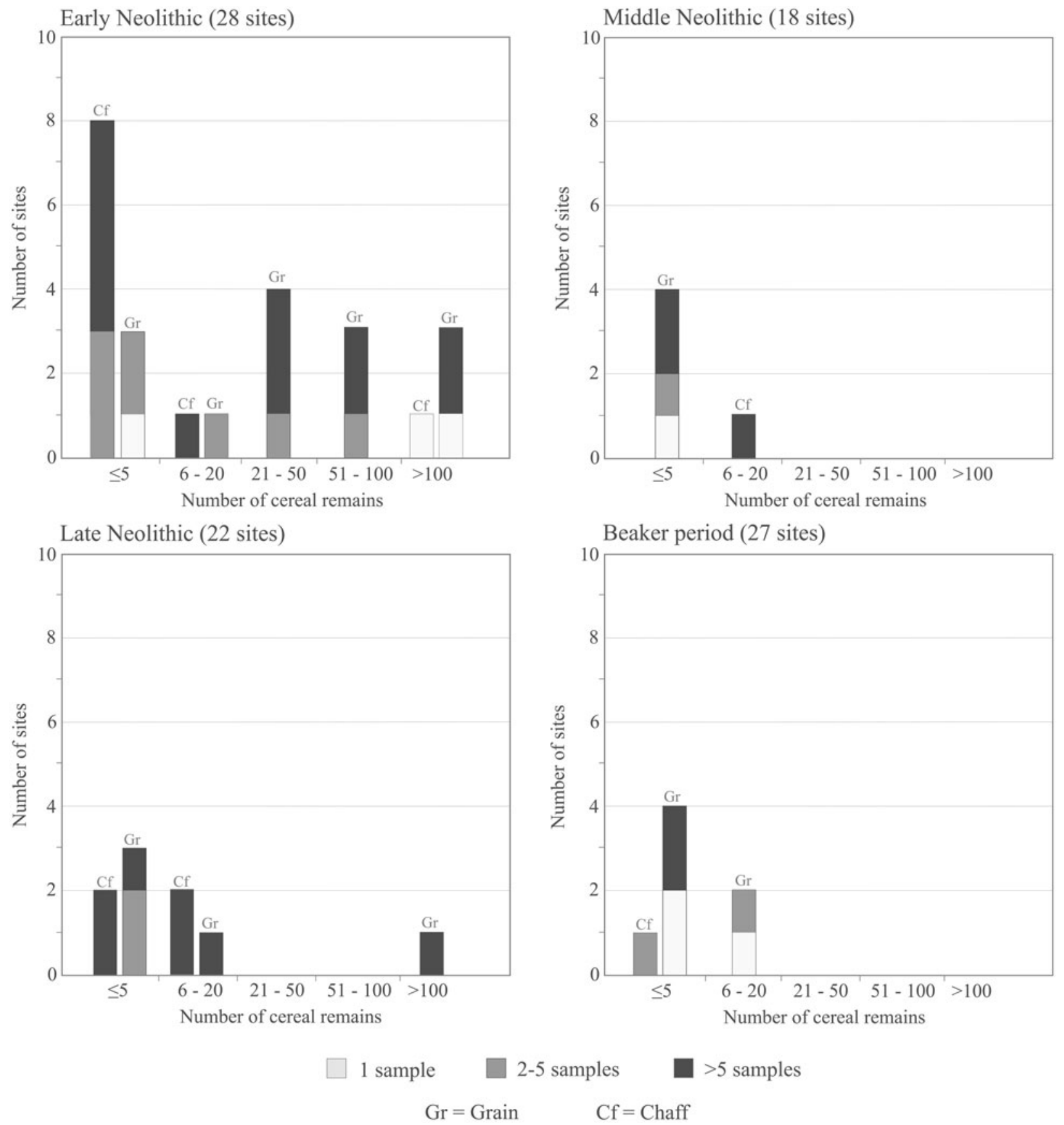

Fig. 7.

Quantity of cereal remains (grains, chaff) recovered for each period displayed in relation to the number of samples taken. Number of sites (in parentheses) refers to the total number of sites for each period 
THE PREHISTORIC SOCIETY

TABLE 5: SUMMARY OF DATA FROM CEREAL-RICH (>100 CEREAL REMAINS)

\begin{tabular}{lccccrr}
\hline Site & Period & $\begin{array}{c}\text { Total } \\
\text { sample } \\
\text { vol (l) }\end{array}$ & $\begin{array}{c}\text { No. } \\
\text { samples }\end{array}$ & $\begin{array}{c}\text { Samples } \\
\text { with }>100 \\
\text { cereals }\end{array}$ & Grain & Chaff \\
\hline Cwmifor (Site 22) & EarlyNeolithic & 187 & 11 & 1 & 273 & 3 \\
Pen-y-Crug (Site 70) & EarlyNeolithic & 208 & 8 & 2 & 573 & 6 \\
Plas Gogerddan (Site 73) & EarlyNeolithic & $4^{\mathrm{a}}$ & 1 & 1 & 722 & 448 \\
Capel Ethinb (Site 11) & Late Neolithic & n.d. & 4 & 2 & 456 & 1 \\
\hline
\end{tabular}

a estimated sample volume; ${ }^{b}$ archaeobotanical data presented in original report differs slightly fro the published summary ( 1 sample has also been excluded); see also endnote 2

TABLE 6: POTENTIAL ARABLE WEEDS RECORDED IN CONTEXTS CONTAINING $\geq 10$ CEREAL GRAINS/CHAFF REMAINS

\begin{tabular}{|c|c|c|c|}
\hline Site & $\begin{array}{c}\text { No. } \\
\text { contexts } \\
\text { where } \\
\text { present }\end{array}$ & $\begin{array}{l}\text { No. } \\
\text { taxa }\end{array}$ & $\begin{array}{l}\text { No. } \\
\text { weed } \\
\text { seeds }\end{array}$ \\
\hline \multicolumn{4}{|c|}{ Early Neolithic } \\
\hline Middle Bastleford (1) (Site 48) & 1 & 1 & 1 \\
\hline Cwmifor (Site 22) & 4 & 5 & 8 \\
\hline Carrog (1) (Site 12) & 1 & 4 & 6 \\
\hline Plas Gogerddan (Site 73) & 1 & 1 & 1 \\
\hline Cwm Meudwy (1) (Site 19) & 1 & 1 & 1 \\
\hline \multicolumn{4}{|c|}{ Middle Neolithic } \\
\hline Upper Ninepence (1) (Site 84) & 1 & 5 & 6 \\
\hline \multicolumn{4}{|c|}{ Late Neolithic } \\
\hline Capel Eithin (3) (Site 11) & 2 & 5 & 31 \\
\hline
\end{tabular}

recorded. The abundant chaff remains may be due to storage in the spikelet form (Caseldine 1992). At all these sites, cereal-rich contexts also produced abundant wild plant remains.

Only one Late Neolithic site, Capel Eithin (Site 11: Williams 1999), produced a large cereal assemblage. In total, 457 cereals $^{2}$ were recovered from four pits (excluding a sample with probable intrusive remains). Most cereals $(91 \%)$ were recovered from two pits and the assemblage is dominated by barley, primarily naked barley. Unfortunately, direct AMS radiocarbon dating of cereals has not been undertaken for this assemblage.

\section{Potential arable weeds}

Analysing the dataset on a context-by-context basis (Table 6), indicates that weed seeds accompanying $\geq 10$ cereal remains were only identified at five Early Neolithic sites (9 contexts), one Middle Neolithic site
( 1 context) and one Late Neolithic site ( 3 contexts). Further data is provided in Table S3. In nearly all cases, the quantity of weed seeds present was very small and most species were recorded in only one site. The species recorded can grow in a range of habitats (disturbed, grassland, freshwater/moorland, woodland edge), though disturbed ground and grassland taxa dominate the assemblages and both annual and perennial species are present. Due to the small quantity of cereal remains it is not possible to reliably interpret cereal cultivation practices from the weed seed data.

\section{Stable carbon $\left(\delta^{13} \mathrm{C}\right)$ and nitrogen $\left(\delta^{15} \mathrm{~N}\right)$ isotope} analysis of Early Neolithic cereal grains

Mean $\delta^{13} \mathrm{C}$ and $\delta^{15} \mathrm{~N}$ values for each site are presented in Table 7 and individually for each sample in Figure 8. Table $\mathrm{S} 5$ includes $\delta^{13} \mathrm{C}, \delta^{15} \mathrm{~N}, \mathrm{C} / \mathrm{N}$ atomic ratio, \% $\mathrm{C}$, and $\% \mathrm{~N}$ results for each sample. Due to potential variability in stable isotope measurements in cereals cultivated under the same conditions and within single cereal ears (Bogaard et al. 2007; Nitsch et al. 2014) it is not possible to assess reliably differences in cereal $\delta^{13} \mathrm{C}$ and $\delta^{15} \mathrm{~N}$ values between sites because of the small sample size.

Mean $\delta^{13} \mathrm{C}$ values for emmer wheat were -24.4 $\pm 0.7 \%$ and for barley were $-25.0 \pm 0.6 \%$ and fall within the expected range for crops growing in good water availability (Wallace et al. 2013). The lower $\delta^{13} \mathrm{C}$ values of barley compared to wheat have been observed in previous studies probably due to a physiological difference between wheat and barley (eg, Ferrio et al. 2005; Wallace et al. 2013). Barley mean $\delta^{15} \mathrm{~N}$ values were $2.5 \pm 2.9 \%$ and emmer wheat mean $\delta^{15} \mathrm{~N}$ values were $0.9 \pm 1.7 \%$ o (excluding possible outlier sample, NCI 047). Emmer wheat $\delta^{15} \mathrm{~N}$ values varied widely from $-2.2 \%$ to $4.5 \%$, however, $40 / 44$ $(91 \%)$ samples fall within the range expected for 
E.R. Treasure et al. NEOLITHIC FARMING \& WILD PLANT EXPLOITATION, WALES

TABLE 7: CEREAL GRAIN NITROGEN $\left(\delta^{15} \mathrm{~N}\right)$ AND CARBON $\left(\delta^{13} \mathrm{C}\right)$ ISOTOPE RESULTS FROM EARLY NEOLITHIC SITES IN WALES

\begin{tabular}{llcrr}
\hline Site & Cereal type & $\begin{array}{c}\text { No. } \\
\text { samples }\end{array}$ & $\delta^{13} \mathrm{C}^{*}{ }^{*}$ & $\delta^{15} \mathrm{~N}^{*}{ }^{*}$ \\
\hline Plas Gogerddan (Site 73) & Emmer wheat & 28 & -25.7 to $-23.6(-24.4 \pm 0.6)$ & -2.2 to $3.4(0.6 \pm 1.7)$ \\
& Barley & 2 & -25.1 to $-24.6(-24.8 \pm 0.4)$ & -0.8 to $1.8(0.5 \pm 1.8)$ \\
Cwm Meudwy (1) (Site 19) & Emmer wheat & 6 & -25.1 to $-23.3(-24.0 \pm 0.7)$ & -0.6 to $4.5(1.5 \pm 1.9)$ \\
& Barley & 1 & -25.8 & 6.1 \\
Gwernvale (Site 33) & Emmer wheat & 6 & -25.8 to $-24.2(-25.1 \pm 0.7)$ & -1.1 to $3.4(2.4 \pm 0.7)$ \\
\multirow{2}{*}{ Parc Bryn Cegin (1) (Site 57) } & Barley & 2 & -25.6 to $-24.9(-25.3 \pm 0.5)$ & 1.6 to $4.9(3.2 \pm 2.4)$ \\
& Barley wheat & 7 & -24.9 to $-22.8(-23.9 \pm 0.7)$ & -1.1 to $7.6(1.6 \pm 2.9)$ \\
& Barley & 1 & -24.3 & 0.4 \\
\hline
\end{tabular}

*Numbers in parenthesis are the mean and associated standard deviation
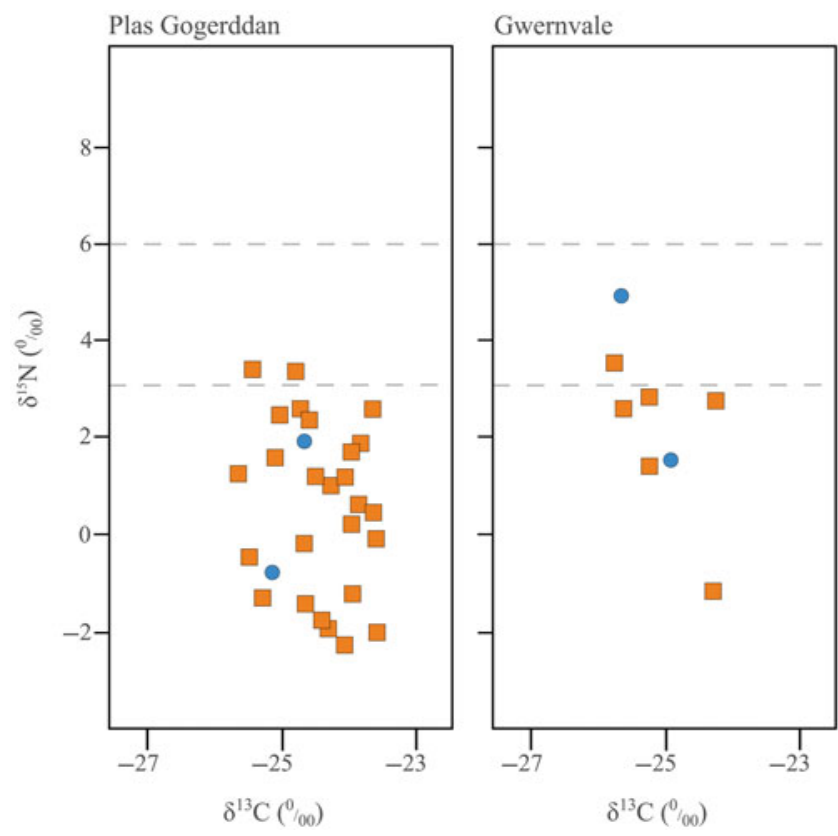
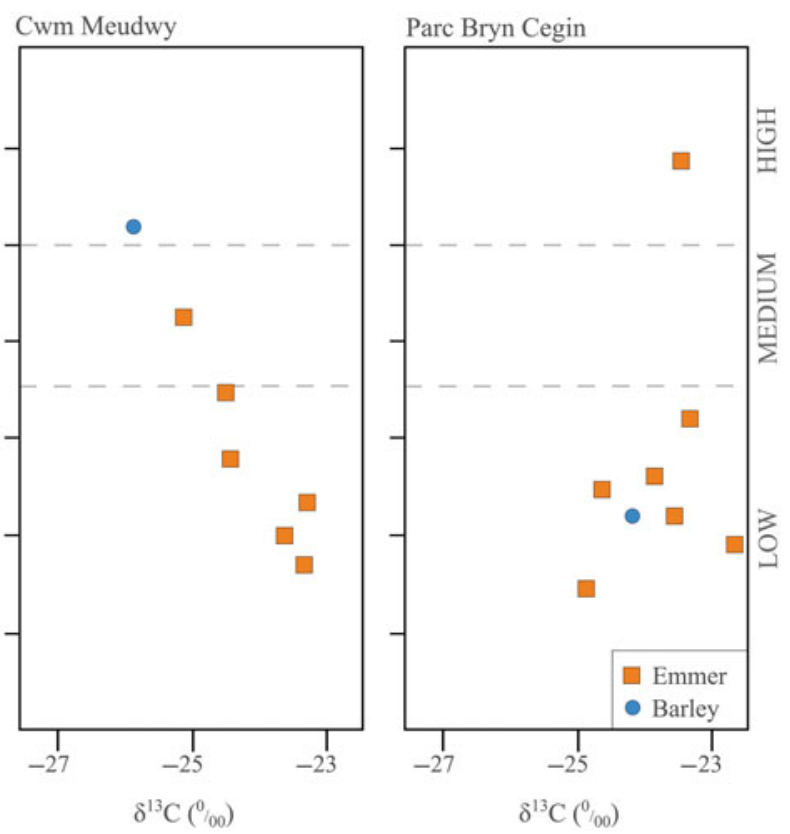

Fig. 8.

Cereal carbon $\left(\delta^{13} \mathrm{C}\right)$ and nitrogen $\left(\delta^{15} \mathrm{~N}\right)$ isotope results from Early Neolithic sites in Wales: Plas Gogerddan (Site 73), Gwernvale (Site 33), Cwm Meudwy (Site 19), \& Parc Bryn Cegin (Site 57). Manuring levels follow Bogaard et al. (2013): 'none or low' $\left(<3 \%\right.$ o $\left.\delta^{15} \mathrm{~N}\right)$, 'medium' $\left(3-6 \% \delta^{15} \mathrm{~N}\right)$ and 'high' $\left(>6 \% \delta^{15} \mathrm{~N}\right)$

low or no manuring (ie, $<3 \%$, following Bogaard et al. 2013). Nearly all the samples from Plas Gogerddan fall in the low or no manuring band. Insufficient data is available to compare barley and emmer wheat $\delta^{15} \mathrm{~N}$ values.

\section{DISCUSSION}

A substantial quantity of archaeobotanical data now exists for Neolithic Wales which can be largely attributed to developer-funded archaeological projects. This provides a valuable comparison to published evidence from Ireland (McClatchie et al. 2014) and other parts of Britain (Jones \& Rowley-Conwy 2007; Bishop et al. 2009; Pelling \& Campbell 2013) as well as continental Europe (eg, Colledge \& Conolly 2007; Salavert 2011; Kirleis et al. 2012; Kirleis \& Fischer 2014; Sørensen \& Karg 2014). The archaeobotanical evidence does not provide evidence for migration or 
acculturation per se, however, it contributes to wider debates surrounding the Mesolithic-Neolithic transition including wild plant use, the introduction and significance of cereals, the nature of farming regimes, and later Neolithic decline in cereal cultivation.

\section{Wild plant use: systematic and intensive?}

There is considerable evidence for the use of wild plants in the Early Neolithic: primarily hazelnuts alongside rarer evidence for other edible fruits and nuts. Excluding hazelnuts, the most commonly represented wild plants in Early Neolithic contexts are raspberry/blackberry and crab apple, though hawthorn, sloe, and acorn were also recorded. Crab apple (both seeds and fruit fragments) were more commonly recorded in Early Neolithic sites than in later periods and a large assemblage was recovered from Plas Gogerddan (Site 73: Caseldine 1992). This range of wild species is comparable to later Mesolithic archaeobotanical assemblages in Wales (eg, Caseldine 2000; Dark 2007; Brown 2007a; McKenna 2014). For the later Neolithic and Beaker periods, evidence for wild plants is also dominated by hazel nutshell and other wild fruits and nuts occur less frequently, though a diverse range of species was recorded. This includes raspberry/blackberry, crab apple, acorn, indeterminate Prunus, sloe, hawthorn, elder, rose (Rosaceae sp.) and parenchyma fragments which could be remains of fruits/tubers. Evidence for these wild fruits/nuts was often restricted to a single site and represented by a small number of identifications.

Hazelnut, crab apple and probably raspberry/ blackberry are best interpreted as deliberately gathered foods, however, in the case of other wild fruits and nuts it is possible that these remains were incorporated into fires unintentionally and are not deliberately gathered. In Early and later Neolithic assemblages in Britain and Ireland, as well as in central and northern European assemblages, hazelnut, raspberry/blackberry, sloe, and crab apple are amongst the most commonly recorded wild plants, whilst other fruits and nuts are often rarer (Jones \& Rowley-Conwy 2007; Bishop et al. 2009; Campbell \& Pelling 2013; McClatchie et al. 2014; for central and northern Europe see Colledge \& Conolly 2007; 2014). However, whilst acorn is commonly recorded in continental European charred/ waterlogged assemblages (Deforce et al. 2013), it is absent in Ireland (McClatchie et al. 2014) and
Scotland (Bishop et al. 2009) and is only recorded at one site in England (Cobain 2014). The occurrence of acorn at five sites in Wales (1 Early Neolithic, 3 later Neolithic, 1 Beaker period) is unusual, though it is possible that these remains were not deliberately gathered. The rarity of acorns may reflect a preservation bias, or rather that acorn was not widely exploited as a food resource (Pelling \& Campbell 2013). Other wild plants may be arable weeds, though plants such as bindweed, recorded at Cwmifor (Site 22: Rackham 2014), and sheep's sorrel, recorded at Carrog (Site 12: Caseldine et al. 2014), could also have been deliberately gathered as foods (Behre 2008; Pelling \& Campbell 2013).

The range of wild plant species recorded probably reflects species which have a higher probability of becoming charred and preserving (Jacomet 2007). For instance, some plants are unlikely to become charred and are difficult to identify (eg, roots, tubers, fruits, leafy vegetables: Zvelebil 1994; KubiakMartens 2002; Hather \& Mason 2002; Colledge \& Conolly 2014). Tubers are rarely recorded in British Neolithic assemblages (eg, Straker 1990; Fairbairn 2000; Wilkinson et al. 2012). In contrast, hazel nutshell is viewed as over-represented as it has a high probability of becoming charred, either deliberately or accidentally, and preserving (Legge 1989; Jones 2000; Jones \& Rowley-Conwy 2007; Bishop et al. 2009; Bishop 2019). Similarly, crab apple and sloe may have been dried, increasing the possibility of charring (Kohler-Schneider 2007; Bishop et al. 2009; 2014). Raspberry/blackberry are light-demanding and are likely to have colonised woodland edges around sites (Colledge \& Conolly 2014), increasing the probably of charring (eg, vegetation burning or incidental inclusion in hearths). Hazelnut, hawthorn, elder, sloe, and rose are also likely to have been common in woodland edges (Colledge \& Conolly 2014). Blackberry/raspberry and elder seeds are also thought to be particularly resistant to decay (Moffett in Hedges et al. 1993; Dark 2007; Carruthers in Rackham 2013a), making them more likely to persist in the soil around sites which would also increase the probability of charring (for instance, below hearths: Sievers \& Wadley 2008). However, it is important to emphasise that some wild plants may have become charred unintentionally and were not deliberately gathered.

Waterlogged assemblages may provide a more representative picture of Neolithic wild plant use (Colledge \& Conolly 2014; Antolín \& Jacomet 2015). A single waterlogged assemblage is available 


\section{E.R. Treasure et al. NEOLITHIC FARMING \& WILD PLANT EXPLOITATION, WALES}

for Wales at Llandevenny (Site 40) that produced abundant remains of raspberry/blackberry and nettle alongside other wild plants, including some charred material (Brown 2007a). However, it is unclear if the plant remains were deliberately gathered or incorporated into fires unintentionally (for instance, vegetation burning: Brown 2007a; cf. Cappers 1993; Sievers \& Wadley 2008; Out 2012). In the wider European context, the significance of wild plants is thought to be considerably under-represented in Neolithic charred archaeobotanical assemblages, though waterlogged assemblages hint at the potentially diverse range of wild plants which could have been exploited (Pelling \& Campbell 2013; Thomas 2014; Colledge \& Conolly 2014).

Ethnographic studies highlight the potential role of hunter-gatherers and farmers in actively modifying environments to promote the growth of certain plants/wood species to increase their productivity for food or to facilitate hunting (Smith 2011; Rowley-Conwy \& Layton 2011). There is growing recognition that wild plants and woodlands may have been managed or altered in the European Mesolithic and Neolithic (Schulting 2008; Jackson \& Ray 2012; Kirleis et al. 2012; Colledge \& Connolly 2014; Barrett 2014; Antolín \& Jacomet 2015; Bishop et al. 2014; 2015; Warren et al. 2014; Jacomet et al. 2016). A challenge is identifying how wild plants and woodlands were exploited using archaeobotanical evidence (Bishop et al. 2014; Warren et al. 2014).

Though hazelnuts are probably over-represented in relative terms, the ubiquity and abundance of hazel nutshell may indicate large-scale and systematic exploitation of hazel (cf. Zvelebil 1994). In addition, since hazelnuts are only available for a short time period in autumn, it is probable that they were stored (Bishop et al. 2014). Crab apples may also have been dried for storage (Caseldine 1992; Kohler-Schneider 2007; Jacomet 2007; Bishop et al. 2014). There is some evidence to indicate the deliberate manipulation of environments to promote the growth of specific plants in the Late Mesolithic and Early Neolithic in the Severn Estuary, south-east Wales (Bell 2007b). It remains a possibility that there was a degree of deliberate manipulation or management of woodlands to promote the growth of hazel alongside other light-demanding species such as crab apple, sloe, and raspberry/blackberry (Colledge \& Conolly 2014). Therefore, the introduction of cereal cultivation should be placed within the context of a 'wild' landscape which was perhaps already being manipulated or managed to some degree, blurring the traditional dichotomy between 'hunter-gathering' and 'farming' (Barrett 2014).

\section{Early Neolithic: The introduction of cereals}

The introduction and uptake of cereals in Wales (c. 3700 cal BC) appears to have been geographically widespread. Cereals were recorded at $57 \%$ of sites (16 sites), however, if sites where plant remains were absent altogether are excluded (5 sites), then the number with cereals increases to $70 \%$. Cereals were primarily recorded at pits/pit groups and rectangular structures/houses, including midden deposits at Gwernvale (Site 33: Caseldine in prep.), reflecting sites with good evidence for occupation deposits. Scant evidence for cereals (not directly dated) was recorded in a shell midden at Nant Hall Road (Site 52: Caseldine 2007) and a causewayed enclosure at Womaston (Site 94: Jones 2009). However, the dataset is biased towards pits/pit groups as few rectangular structures/ houses, funerary, and monumental sites have been excavated recently and sampled for plant remains.

Wheat was the dominant crop-type, most likely emmer wheat, though barley is commonly recorded and evidence for other cereals (naked wheat, oat) is very limited. Where barley was present, it is likely that the naked variety was dominant (cf. Pelling \& Campbell 2013). Oat may have been a weed, though it is unclear if these remains are intrusive (oat was widely cultivated in later periods: Schmidl et al. 2008; McKenna 2013; cf. McClatchie et al. 2016). The status of naked wheat as a crop is unclear since it is commonly intrusive in British Neolithic contexts (Pelling et al. 2015). There is no unequivocal evidence for einkorn wheat (Triticum monococcum L.) and no evidence for oil crops (flax, poppy - Papaver sp.) or pulses (Celtic bean, pea - Pisum sativum L.) in the Early Neolithic.

The range of cereal-types recorded in Early Neolithic Wales is comparable to other evidence from central/southern Britain and Ireland where emmer wheat is the main crop, whilst einkorn is very rare (Straker 1990; Jackson \& Ray 2012; Jones \& Rowley-Conwy 2007; Bishop et al. 2009; Pelling \& Campbell 2013; McClatchie et al. 2014). Barley, primarily naked barley, is frequently recorded in Britain and Ireland though it appears to have been of secondary importance to emmer wheat (Pelling \& Campbell 2013; McClatchie et al. 2014), except in areas of Scotland (Bishop et al. 2009). Naked wheat grains 
are common, though typically a minor component of assemblages and in many cases are intrusive (Pelling \& Campbell 2013; Pelling et al. 2015). Other crops are recorded sporadically including flax and poppy (Jones \& Rowley-Conwy 2007; Campbell \& Robinson 2007), whilst pulse crops (pea, Celtic bean) appear absent (Treasure \& Church 2017). The range of cereal types present contrasts with central and northern European sites where einkorn is commonly recorded and naked wheat also appears to have been a more important crop (eg, Kreuz 2007; Salavert 2011; Kirleis et al. 2012; Kirleis \& Fischer 2014). Overall, it is apparent that there was a substantial degree of uniformity, rather than regional diversity, in Early Neolithic archaeobotanical assemblages in both the cereal-types and wild plants recorded across most of Britain and Ireland.

The widespread uptake of cereals in Early Neolithic Wales does not provide evidence for migration per se, however, it is perhaps more consistent with models of the Neolithic transition which prioritise the migration of farmers (eg, Rowley-Conwy 2004; 2011; Sheridan 2010; Stevens \& Fuller 2012). Despite this, indigenous hunter-gatherers probably adopted and diffused cereals to some extent, possibly cultivating cereals or acquiring them via exchange (eg, Thomas 2014). To address this in more detail, direct AMS radiocarbon dating of cereals from sites in Wales is required to assess the timing of their introduction and its relationship to wider changes in the archaeological record (Griffiths 2018). Other lines of evidence provide compelling evidence for migration in this period including strontium isotope analyses of Early Neolithic human remains in south-east Wales (Neil et al. 2017) and large-scale aDNA studies (Brace et al. 2019). A sharp demographic increase coeval with the introduction of farming in Britain and Ireland is also indicated (Stevens \& Fuller 2012; McLaughlin et al. 2016), possibly during a period of warming climate (Warden et al. 2017; cf. Dark \& Gent 2001). Wider changes in subsistence practices are also present, with indications of a shift in diets away from marine resources (Schulting et al. 2013).

\section{Early Neolithic: the significance of cereals in subsistence practices}

Cereals were typically present in low-densities and cereal-rich contexts are uncommon (ie, $>100$ grains/ chaff remains). The low-density of cereals in Early
Neolithic sites is typical of British and Irish assemblages, as well as central European LBK and northern European TRB assemblages (Bogaard \& Jones 2007; Jones \& Rowley-Conwy 2007; Kreuz 2007; Robinson 2007; Bishop et al. 2009; Salavert 2011; Kirleis et al. 2012; McClatchie et al. 2014). This is likely to reflect a combination of taphonomic factors and the scale of cereal production. For instance, cereals are unlikely to become charred, unless accidentally burnt (Jones \& Rowley-Conwy 2007) and are likely to be under-represented at sites where only limited sampling was undertaken, as is the case for most Early Neolithic sites in Wales (Jones 2000; Jones \& Rowley-Conwy 2007; Jones \& Legge 2008; Bishop et al. 2009; McClatchie et al. 2014). Equally, there is an 'element of chance' in the recovery of cereal-rich assemblages, necessitating large-scale sampling (Jones 2000; Pelling \& Campbell 2013). Considering these taphonomic factors, the important point here is that cereals occur consistently, suggesting that cereals were an important component of subsistence practices (Stevens 2007; Jones \& Rowley-Conwy 2007; McClatchie et al. 2016). Variability in the quantity of cereal remains recovered may reflect local/regional variations (Bishop 2015), though disentangling the impact of taphonomic factors is difficult.

Whilst cereal grains are widely present across Early Neolithic Wales, chaff and weed seeds are remarkably rare. This is typical of Early Neolithic assemblages in Britain, Ireland, and southern Scandinavia, though it presents a marked contrast to LBK assemblages (Robinson 2000; Colledge et al. 2005; Kreuz 2007; Stevens 2007; Bogaard \& Jones 2007; Bishop et al. 2009; see also Robinson 2007 and Sørensen \& Karg 2014). The rarity of chaff may reflect several factors, for example dehusking of emmer wheat by pounding or rubbing, rather than parching (Robinson 2000, 88 ), or off-site crop processing which reduces the risk of accidental charring or storage of clean grain (Robinson 2000; Kreuz 2007; Stevens 2007; Jones \& Rowley-Conwy 2007; Bogaard \& Jones 2007; Bishop et al. 2009). Storing clean grain is interesting as the resulting crop is more portable and this could have some connection with the degree of residential mobility as well as the exchange/movement of cereals (Stevens 2007; Thomas 2014). The by-products of cereal processing are viewed as characteristic markers of local cultivation and it is often assumed, rather than proven, that cereals recovered from Neolithic sites were locally cultivated (cf. Hillman 1982). The movement 


\section{E.R. Treasure et al. NEOLITHIC FARMING \& WILD PLANT EXPLOITATION, WALES}

and/or exchange of cereals is a factor which requires further attention (Deforce et al. 2013; cf. Bishop 2015; Meylemans et al. 2018).

\section{Early Neolithic: Assessing cereal cultivation practices through weed ecology and cereal isotope measurements}

Considerable research has focused on identifying the introduction of cereals; however, less attention has been directed towards understanding the nature of early farming practices (Bogaard 2005). In part, this reflects the rarity of weed seeds in Neolithic assemblages (Bogaard 2014; Stevens \& Fuller 2018). This rarity potentially reflects harvesting techniques (ie, gathering of cereal ears), crop-processing methods (ie, careful crop cleaning), or cultivation practices (Colledge et al. 2005; Jacomet et al. 2016; Stevens \& Fuller 2018). Slash-and-burn cultivation regimes may account for the rarity of weed seeds (Robinson 2007; Rösch et al. 2014; 2017), however, the evidence for this is equivocal since weeds may be rare for several years in plots recently cleared of trees (Halstead 2018).

The few weed seeds present in Neolithic Wales do not permit detailed interpretations of crop cultivation practices. Species recorded include annuals and perennials which can grow in a range of habitats, though taxa of disturbed and grassland habitats were dominant, and this is typical of assemblages in Britain and Ireland (Bogaard \& Jones 2007; Pelling \& Campbell 2013; McClatchie et al. 2014). Though the dataset is very limited, evidence for perennial species typical of woodland habitats was minimal, as would be expected under a shifting cultivation regime (cf. Bogaard 2002). Analyses of potential arable weeds in Britain and Ireland also suggests that cereals were cultivated in long-lived (>10 years) plots (Bogaard \& Jones 2007; McClatchie et al. 2014), however the dataset for Wales is too small to investigate this.

Stable isotope analyses of cereals can be used to investigate directly cultivation conditions of specific cereal-types, independently of weed seed data (Bogaard 2014). In particular, cereal $\delta^{15} \mathrm{~N}$ values have been used to identify manuring in Neolithic Europe, however, samples have only been analysed from a small number of Early Neolithic sites (Bogaard et al. 2013; Kanstrup et al. 2014; Styring et al. 2016; 2017; Gron et al. 2017). The cereal isotope measurements for Early Neolithic Wales provide an important contribution to this dataset. Though the sample size is small, at the time of analysis it represented the best available material. This approach is valuable when small samples of cereal grains from several sites are combined, particularly considering the lack of wellpreserved cereal assemblages.

Cereal $\delta^{15} \mathrm{~N}$ values for Early Neolithic Wales largely fall within the 'no manuring or low manuring' range. Short-term manuring (ie, 1-2 years) cannot be excluded since this has a less significant and more variable impact on $\delta^{15} \mathrm{~N}$ values (Fraser et al. 2011). In addition, there is some evidence for the cultivation of 'middens' in Early Neolithic Wales (Nant Hall Road, Site 52: Bell 2007b) and elsewhere in southern Britain (Guttmann 2005). The impact of midden cultivation on cereal $\delta^{15} \mathrm{~N}$ values is unclear, however, it is likely to elevate cereal $\delta^{15} \mathrm{~N}$ values. Despite this, the cereal isotope results suggest that long-term, intensive manuring was not undertaken at the sites analysed. Cereals may have been cultivated in low-intensity regimes on poor soils, assuming they were locally cultivated. This evidence contrasts with currently published data from Early Neolithic sites in Europe.

To analyse the earliest farming practices in Neolithic Europe, Figure 9 compares the results for Early Neolithic Wales with evidence from Early Neolithic sites in England, southern Scandinavia, and south-western Germany. In England, 'high' $\delta^{15} \mathrm{~N}$ values were recorded in a rectangular structure/house at Lismore Fields, Derbyshire (c. 3810-3600 cal BC) suggesting long-term intensive manuring (Jones \& Bogaard 2017), whilst slightly lower $\delta^{15} \mathrm{~N}$ values from a causewayed enclosure at Hambledon Hill, Dorset (c. 3700$3300 \mathrm{cal} \mathrm{BC}$ ) may indicate less intensive/shorter-term manuring (Bogaard et al. 2013; Jones \& Bogaard 2017). At Stensborg (c. 3700-3360 cal BC), southern Scandinavia, Gron et al. (2017) identified evidence for long-term intensive manuring, though variation is present and $\delta^{15} \mathrm{~N}$ values range from 'low' to 'high', with emmer wheat and naked wheat more intensively manured than barley. Evidence for intensive manuring was also identified at LBK Vaihingen (c. 5500-5070 cal $\mathrm{BC})$ and Viesenhäuser Hof (c. 5500-4000 cal BC, data not presented in Fig. 9), south-western Germany (Bogaard et al. 2013; Styring et al. 2017).

The evidence from Early Neolithic Wales contrasts with this general pattern of intensive manuring recorded at other European Early Neolithic sites, though variability is present. For instance, samples within the 'low' to 'no manuring' range were identified at Stensborg (Gron et al. 2017), as well as in the later 


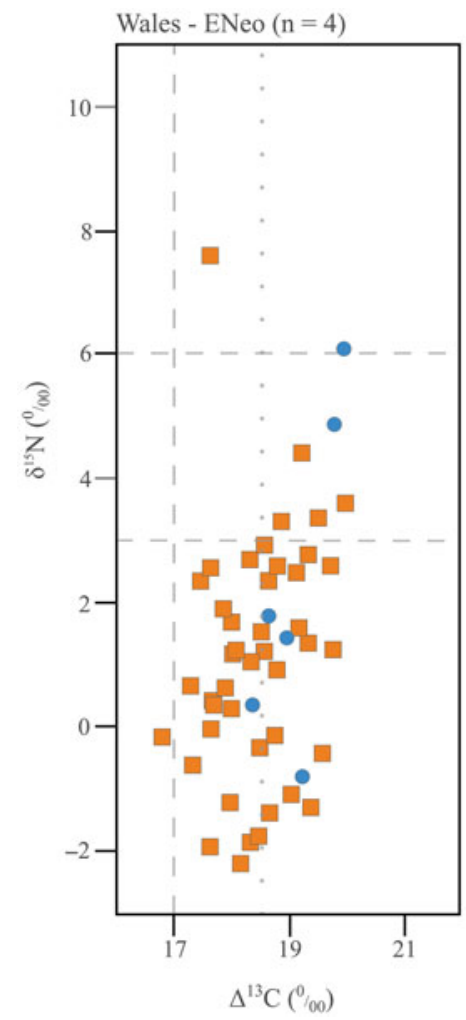

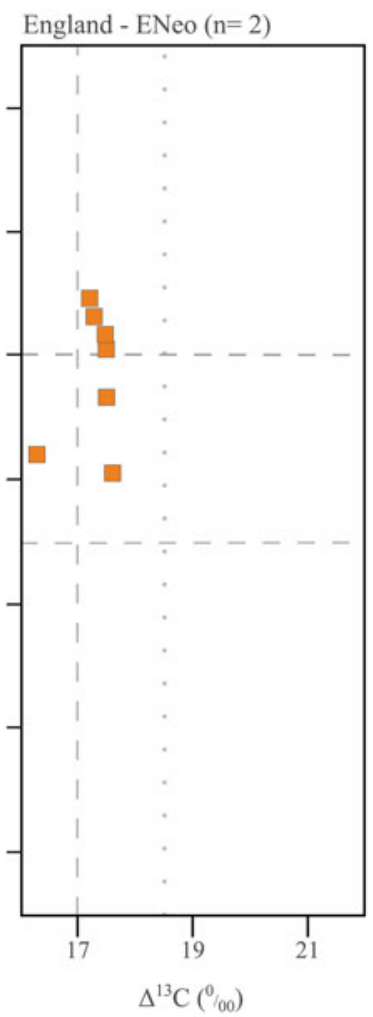

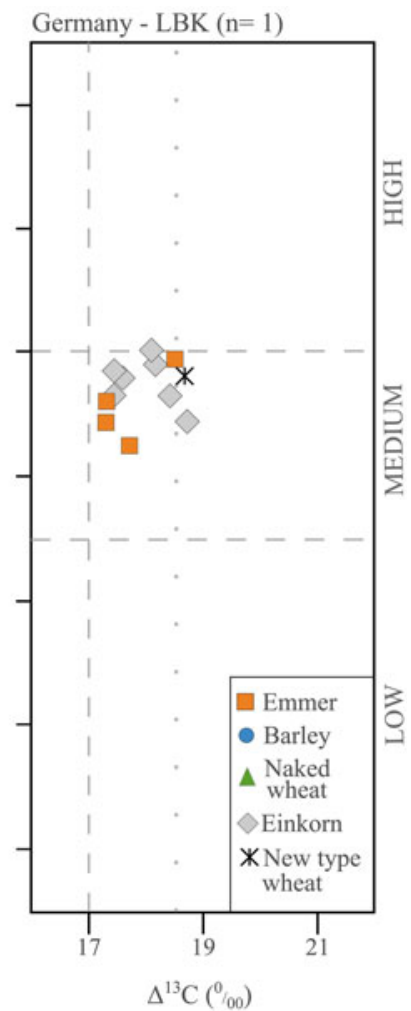

Fig. 9.

Cereal grain carbon $\left(\Delta^{13} \mathrm{C}\right)$ and nitrogen $\left(\delta^{15} \mathrm{~N}\right)$ results for Early Neolithic Wales compared with Early Neolithic data from England, Sweden, \& Germany. Note that cereal $\Delta^{13} \mathrm{C}$ values are presented (opposed to $\delta^{13} \mathrm{C}$ values) to enable comparison between sites of different periods. Manuring levels follow Bogaard et al. (2013): 'none or low' $\left(<3 \%\right.$ o $\left.\delta^{15} \mathrm{~N}\right)$, 'medium' (3-6\%o $\left.\delta^{15} \mathrm{~N}\right)$ and 'high' $\left(>6 \%\right.$ o $\left.\delta^{15} \mathrm{~N}\right)$. The vertical dashed line represents well-watered wheat $\left(17 \% \circ \Delta^{13} \mathrm{C}\right)$ and the vertical dotted line represents well-watered barley (18.5\% $\left.\Delta^{13} \mathrm{C}\right)$, based on Wallace et al. (2013). The cereal data for Wales (this paper) and Sweden (Gron et al. 2017) are based on single entity samples, whereas the data from England and Germany (Bogaard et al. 2013) are bulk samples

site of Sarup (3400-2900 cal BC) southern Scandinavia (Bogaard et al. 2013). Variability in cultivation conditions would be expected in small-scale, mixed farming regimes (Bogaard 2005).

The identification of manuring is significant since it is a key component of intensive mixed farming regimes, requiring a close integration between animal and crop husbandry (Bogaard 2012). Manuring is also a labour-intensive process, probably associated with the cultivation of permanent plots and with labour organised at the household level (Bogaard 2005; Jones 2005). Whilst regional variability existed, it is suggested that onset of the Neolithic in Europe was characterised by the relatively uniform introduction of a 'package' of intensive cultivation in permanent plots integrated with animal husbandry (Bogaard
2004; 2005; Jones 2005; Halstead 2006; Bogaard et al. 2013; 2016; Whitehouse et al. 2014; Jacomet et al. 2016; Gron et al. 2017; Jones \& Bogaard 2017).

At Lismore Fields there is strong evidence for an intensive mixed farming regime with cultivation in permanent plots (Jones and Bogaard 2017). An extremely large cereal assemblage was recovered from this site, which may be atypical (Thomas 2014), and the results should not be uncritically extrapolated to other areas (Jones \& Bogaard 2017). This is demonstrated by the cereal isotope measurements for Early Neolithic Wales, which do not provide evidence for an intensive mixed farming regime. This may reflect a lack of integration between crop and animal husbandry, with the less-intensive and opportunistic clearings for cultivation (cf. Brown 1997; 


\section{E.R. Treasure et al. NEOLITHIC FARMING \& WILD PLANT EXPLOITATION, WALES}

Thomas 2003, 71). However, a larger dataset, combining weed ecology and cereal isotope measurements (Bogaard et al. 2016) is required to examine this in greater detail and to identify wider parallels for this pattern in Britain and Ireland.

\section{Later Neolithic and Beaker period: Evidence for a cereal decline?}

It is widely recognised that evidence for cereals decreases in the later Neolithic across many areas of Britain and Ireland (Moffett et al. 1989; Robinson 2000; Brown 2007b; Stevens \& Fuller 2012; Pelling \& Campbell 2013; McClatchie et al. 2016). Evidence from later Neolithic and Beaker period sites in Wales also points to a decrease in the number of sites with cereals and the quantity of cereals present. The evidence for a decline in cereals may also be over-exaggerated due to taphonomic factors, since many funerary/monumental sites and burnt mounds (opposed to 'occupation' sites) have been sampled and charred plant remains are rare in these sites (Robinson 2000; Pelling \& Campbell 2013; McClatchie et al. 2016). However, despite this, cereals are comparatively rarer in later Neolithic and Beaker period pits/pit groups than in the Early Neolithic. One exception is Capel Eithin, Anglesey (Site 11: Williams 1999), which produced a large cereal assemblage (not directly dated), comprising $>400$ grains. Overall, however, cereals occur less frequently and in smaller quantities than in the preceding Early Neolithic, perhaps reflecting a later Neolithic decline in cereal cultivation. Evidence for the increasing importance of pastoralism in the later Neolithic (eg, Worley et al. 2019) is lacking due to the absence of faunal remains (see, however, Dudd et al. 1999).

Cereals also become a smaller component of later Neolithic assemblages in Ireland (McClatchie et al. 2014; 2016), southern Scotland (Bishop et al. 2009; Bishop 2015), and England, particularly in southern areas (Robinson 2000; Pelling \& Campbell 2013; Worley et al. 2019). Stevens and Fuller (2012) suggest a major decline, or even abandonment, of cereal cultivation in the later Neolithic across much of Britain based primarily on the small number of directly dated cereal grains for this period. This may, however, reflect a sample selection bias in radiocarbon dating (Bishop 2015; Jones \& Bogaard 2017). Areas of cereal cultivation may also have persisted throughout the later Neolithic, particularly in north-east Scotland and the Scottish Islands (Bishop 2015). In addition, a Late Neolithic deposit of several thousand barley grains (directly dated) was identified at Clifton Quarry in the Welsh Marches (Jackson \& Ray 2012) and Late Neolithic cereal-rich deposits are recorded in northern England (Huntley 1996). Consequently, Stevens and Fuller's (2012) research is an important large-scale narrative, however, it inevitably overlooks subtle and important regional diversity. It is not possible to directly evaluate the importance of cereals in later Neolithic and Beaker period Wales in greater detail due to the lack of direct AMS radiocarbon dates on cereal remains to rule out intrusive remains (for example, Parc Bryn Cegin, Site 61, Gwynedd: Kenney 2008; Burrow 2017; cf. Stevens \& Fuller 2012, 11; Pelling et al. 2015).

Where cereals are recorded in later Neolithic and Beaker period sites in Wales, emmer wheat and barley are usually identified, however, evaluating the relative importance of different cereal types is difficult due to the rarity of cereal remains. Barley was recorded at marginally more Middle Neolithic and Beaker period sites than wheat and the large Late Neolithic assemblage from Capel Eithin (Site 11: Williams 1999) was dominated by barley. This may reflect a more gradual shift towards barley, particularly naked barley, in Early and later Bronze Age Wales (eg, Caseldine 1990; Britnell et al. 1997; Caseldine \& Griffiths 2004; Carruthers 2011; 2013; Archaeological Services Durham University 2013; Rackham 2013b; Smith et al. 2017). Barley, particularly naked barley, may have increased in importance in later Neolithic in England (Jones \& Rowley-Conwy 2007, table 23.1), possibly in Ireland (McClatchie et al. 2014), and in Scotland (Bishop et al. 2009; Bishop 2015). In other areas of Europe, barley also appears to increase in importance in the later Neolithic (Jacomet 2007; Robinson 2007), possibly reflecting declining climatic conditions in the later Neolithic (Stevens \& Fuller 2012; Bishop 2015).

\section{CONCLUSION}

This paper represents the most comprehensive review of archaeobotanical data undertaken to date for Neolithic Wales. The large increase in the quantity of data, both published and unpublished, can largely be attributed to developer-funded archaeological projects.

Cereals are widely present across Early Neolithic Wales alongside substantial evidence for wild plant use, notably hazelnuts and wild fruits. A similar range 
of wild plant remains were recovered from Middle Neolithic, Late Neolithic, and Beaker period sites. It is possible that wild plants and woodlands were deliberately managed/altered to promote the growth of plants such as hazel and other light-demanding species. Though cereals typically occur in small quantities in the Early Neolithic, it is argued that the widespread and consistent occurrence of cereals indicates that they were a significant component of subsistence practices. Wheat, most likely emmer, appears to be main crop in the Early Neolithic and evidence for other crops is slight. Cereal cultivation practices were investigated through analysis of potential arable weeds and cereal isotope analysis on Early Neolithic sites. Insufficient weed seed data was available, however, cereal nitrogen isotope $\left(\delta^{15} \mathrm{~N}\right)$ values identified no evidence for intensive manuring, contrasting with published evidence for Early Neolithic sites in other areas of northern Europe. This may suggest that cultivation conditions were less-intensive than in other areas of Britain and Europe. For the Middle Neolithic, Late Neolithic, and Beaker period, evidence for a decline in cereals was identified, however, further data are required to evaluate this in greater detail.

Acknowledgements: This research formed part of an AHRCfunded MA by Research awarded to ERT (Grant Number: AH/L002558/1). E. Treasure would like to thank the following for providing access to unpublished archaeobotanical data: Archaeological Services Durham University, Clwyd-Powys Archaeological Trust, Dyfed Archaeological Trust, Gwynedd Archaeological Trust, Glamorgan-Gwent Archaeological Trust and Worcestershire Archive and Archaeology Service. Gwynedd Museum \& Art Gallery is thanked for permission to access sample cereal grains from Parc Bryn Cegin and Anglesey Archives is also thanked for providing access to the excavation archive for Capel Eithin. We also thank the reviewers for their constructive comments.

\section{SUPPLEMENTARY MATERIAL}

To view supplementary material for this article, please visit https://doi.org/10.1017/ppr.2019.12

\section{NOTES}

1. A large mesh size $(1 \mathrm{~mm})$ was used and consequently smaller weed seeds may be under-represented. The residue was also discarded prior to it being checked for plant remains.

2. It is assumed that the cereal assemblage was dominated by grain, rather than chaff, however, conflicting information is provided in the original archaeobotanical report.

\section{BIBLIOGRAPHY}

Aguilera, M., Zech-Matterne, V., Lepetz, S. \& Balasse, M. 2017. Crop fertility conditions in north-eastern Gaul during the La Tène and Roman periods: a combined stable isotope analysis of archaeobotanical and archaeozoological remains. Environmental Archaeology 23, 323-37

Anderson-Whymark, H. \& Thomas, J. (eds) 2012. Regional Perspectives on Neolithic Pit Deposition: Beyond the mundane. Oxford: Neolithic Studies Group Seminar Papers 12

Antolín, F. \& Jacomet, S. 2015. Wild fruit use among early farmers in the Neolithic (5400-2300 cal BC) in the northeast of the Iberian Peninsula: an intensive practice? Vegetation History and Archaeobotany 24, 19-23

Archaeological Services Durham University 2013. 2011 Excavation Borras Quarry, Wrexham. Palaeoenvironmental analysis. Durham: Archaeological Services Durham University, unpublished Report 2988

Barber, A. \& Hart, J. 2014. South Wales Gas Pipeline Project. Site 26.05. Land West of Cwmifor, Manordeilo and Salem, Camarthenshire. Archaeological Excavation. Cirencester: Cotswold Archaeology, unpublished Report 13308

Barber, A. \& Hart, J. 2015. South Wales Gas Pipeline Project. Site 503. Land East of Vaynor Farm, Llanddowror, Camarthenshire. Archaeological Excavation. Cirencester: Cotswold Archaeology unpublished Report 9150

Barrett, J.C. 2014. Some possible conditions necessary for the colonisation of Europe by domesticates. In Whittle \& Bickle (eds) 2014, 39-51

Batchelor, C.R., Branch, N.P., Allison, E.A., Austin, P.A., Bishop, B., Brown, A.D., Elias, S.A., Green, C.P. \& Young, D.S. 2014. The timing and causes of the Neolithic elm decline: new evidence from the Lower Thames Valley (London, UK). Environmental Archaeology 19, 263-90

Behre, K.E. 2008. Collected seeds and fruits from herbs as prehistoric food. Vegetation History and Archaeobotany 17, 65-73

Bell, M. 2007a. Mesolithic coastal communities in western Britain: conclusions. In Bell (ed.) 2007c, 318-42

Bell, M. 2007b. The Mesolithic and Neolithic in the coastal zone of western Britain. In Bell (ed.) 2007c, 1-18

Bell, M. (ed.). 2007c. Prehistoric Coastal Communities: The Mesolithic in western Britain. York: Council for British Archaeology Research Report 149

Bell, M. \& Noble, G. 2012. Prehistoric woodland ecology. In A.M. Jones, J. Pollard, M.J. Allen \& J. Gardiner (eds), Image, Memory and Monumentality: Archaeological engagements with the modern world, 80-92. Oxford: Prehistoric Society Research Papers 5

Bickle, P. \& Whittle, A. 2014. Integrated and multi-scalar approaches to early farmers in Europe. In Whittle \& Bickle (eds) 2014, 1-20

Bishop, R.R. 2015. Did Late Neolithic farming fail or flourish? A Scottish perspective on the evidence for Late Neolithic arable cultivation in the British Isles. World Archaeology 47, 834-55 


\section{E.R. Treasure et al. NEOLITHIC FARMING \& WILD PLANT EXPLOITATION, WALES}

Bishop, R.R. 2019. Experiments on the effects of charring on hazelnuts and their representation in the archaeological record. Journal of Archaeological Science: Reports 26, 101839

Bishop, R.R., Church, M.J. \& Rowley-Conwy, P.A. 2009. Cereals, fruits and nuts in the Scottish Neolithic. Proceedings of the Society of Antiquaries of Scotland 139, 47-103

Bishop, R.R., Church, M.J. \& Rowley-Conwy, P.A. 2014. Seeds, fruits and nuts in the Scottish Mesolithic. Proceedings of the Society of Antiquaries of Scotland 143, 9-72

Bishop, R.R., Church, M.J. \& Rowley-Conwy, P.A. 2015. Firewood, food and human niche construction: the potential role of Mesolithic hunter-gatherers in actively structuring Scotland's woodlands. Quaternary Science Reviews 108, 51-75

Bocherens, H. \& Drucker, D. 2003. Trophic level isotopic enrichment of carbon and nitrogen in bone collagen: Case studies from recent and ancient terrestrial ecosystems. International Journal of Osteoarchaeology 13, 46-53

Bogaard, A. 2002. Questioning the relevance of shifting cultivation to Neolithic farming in the loess belt of Europe: evidence from the Hambach Forest experiment. Vegetation History and Archaeobotany 11, 155-68

Bogaard, A. 2004. Neolithic Farming in Central Europe: An archaeobotanical study of crop husbandry practices. London: Routledge

Bogaard, A. 2005. 'Garden agriculture' and the nature of early farming in Europe and the Near East. World Archaeology 37, 177-96

Bogaard, A. 2012. Middening and manuring in Neolithic Europe: issues of plausibility, intensity and archaeological method. In R. Jones (ed.), Manure Matters: Historical, archaeological and ethnographic perspectives, 25-39. Farnham: Ashgate

Bogaard, A. 2014. Framing farming: a multi-stranded approach to early agricultural practice in Europe. In Whittle \& Bickle (eds) 2014, 181-96

Bogaard, A. \& Jones, G. 2007. In Whittle \& Cummings (eds) 2007, 357-76

Bogaard, A., Heaton, T.H.E, Poulton, P. \& Merbach, I. 2007. The impact of manuring on nitrogen isotope ratios in cereals: archaeological implications for reconstruction of diet and crop management practices. Journal of Archaeological Science 34, 335-43.

Bogaard, A. Fraser, R., Heaton, T.H.E. Wallace, M. Vaiglova, P., Charles, M., Jones, G., Evershed, R.P., Styring, A.K., Andersen, N.H. \& Arbogast, R.M. 2013. Crop manuring and intensive land management by Europe's first farmers. Proceedings of the National Academy of Sciences of the United States of America 110, 589-94

Bogaard, A., Hodgson, J., Nitsch, E., Jones, G., Styring, A.K., Diffey, C., Pouncett, J., Herbig, C., Charles, M., Ertuğ, F., Tugay, O., Filipovic, D. \& Fraser, R. 2016. Combining functional weed ecology and crop stable isotope ratios to identify cultivation intensity: a comparison of cereal production regimes in Haute Provence, France and Asturias, Spain. Vegetation History and Archaeobotany 25, 57-73
Boivin, N., Fuller, D.Q. \& Crowther, A. 2012. Old World globalization and the Columbian exchange: comparison and contrast. World Archaeology 44, 452-69

Brace, S., et al. 2019. Ancient genomes indicate population replacement in Early Neolithic Britain. Nature Ecology \& Evolution 3, 765-71

Brinkkemper, O., Braadbaart, F., van Os, B., van Hoesel, A., van Brussel, A.A.N. \& Fernandes, R. 2018. Effectiveness of different pre-treatments in recovering pre-burial isotopic ratios of charred plants. Rapid Communications in Mass Spectrometry 32, 251-61

Britnell, W.J. 1982. The excavation of two round barrows at Trelystan, Powys. Proceedings of the Prehistoric Society 48, 133-201

Britnell, W.J. 1984. The Gwernvale long cairn, Crickhowell, Brecknock. In W.J. Britnell \& H.N. Savory (eds), Gwernvale and Penywyrlod: Two Neolithic long cairns in the Black Mountains of Brecknock, 43-154. Cardiff: Cambrian Archaeological Monographs 2

Britnell, W.J. \& Jones, N.W. 2012. Large late Neolithic and early Bronze Age ring-ditches in Wales. Archaeologia Cambrensis 161, 165-98

Britnell, W.J., Silvester, R.J., Gibson, A.M., Caseldine, A.E., Hunter, K.L., Johnson, S., Hamilton-Dyer, S. \& Vince, A. 1997. A Middle Bronze Age Round-house at Glanfeinion, near Llandinam, Powys. Proceedings of the Prehistoric Society 63, 179-97

Brown, A. 2007a. Mesolithic to Neolithic human activity and impact at the Severn Estuary wetland edge: studies at Llandevenny, Oldbury Flats, Hills Flats, and Woolaston. In Bell (ed.) 2007c, 249-62

Brown, A. 2007b. Dating the onset of cereal cultivation in Britain and Ireland: the evidence from charred cereal grains. Antiquity 81, 1042-52

Brown, A.D. 2013. Bronze Age vegetation history and human activity at Llandevenny and in the wider Severn Estuary region. In M. Bell (ed.), The Bronze Age in the Severn Estuary, 274-88. York: Council for British Archaeology Research Report 172

Brown, A.G., Davis, S.R., Hatton, J. O'Brien, C., Reilly, F. Taylor, K., Dennehy, K.E., O’Donnell, L., Bermingham, N., Mighall, T., Timpany, S., Tetlow, E., Wheeler, J. \& Wynne, S. 2016. The environmental context and function of burnt mounds: new studies of Irish Fulachtai Fiadh. Proceedings of the Prehistoric Society 82, 259-90

Brown, T. 1997. Clearances and clearings: deforestation in Mesolithic/Neolithic Britain. Oxford Journal of Archaeology 16, 133-46

Burrow, S. 2003. Catalogue of the Mesolithic and Neolithic Collections at the National Museums and Galleries of Wales. Cardiff: National Museum of Wales

Burrow, S. 2017. Radiocarbon analysis in Wales: the state of the nation. Archaeology in Wales 56, 107-12

Campbell, G. \& Robinson, M. 2007. Environment and land use in the valley bottom. In J. Harding \& F. Healy (eds), The Raunds Area Project: A Neolithic and Bronze Age landscape in Northamptonshire, 18-36. Swindon: English Heritage 
Cappers, R.T.J. 1993. Seed dispersal by water: a contribution to the interpretation of seed assemblages. Vegetation History and Archaeobotany 2, 173-86

Carruthers, W.J. 2011. Charred plant remains. In P. Crane \& K. Murphy, Early Medieval settlement, iron smelting and crop processing at South Hook, Herbranston, Pembrokeshire, 2004-05, 163-81. Archaeologia Cambrensis 159, 117-95

Carruthers, W.J. 2013. Assessment of the charred plant remains. In M. Houliston, Land at Penrhosgarnedd, Bangor, Gwynedd. Archaeological Evaluation, 19-22. Llanidloes: Archaeology Wales unpublished Report 1163

Caseldine, A.E. 1990. Carbonized plant remains. In D.G. Benson, J.G. Evans, G.H. Williams, T. Darvill \& A. David, Excavations at Stackpole Warren, Dyfed, 229. Proceedings of the Prehistoric Society 56, 179-245

Caseldine, A.E. 1992. The Neolithic carbonized plant remains from pit 206. In K. Murphy, Plas Gogerddan, Dyfed: a multi-period burial and ritual site, 24-6. Archaeological Journal 149, 1-38

Caseldine, A.E. 1999. The charred plant remains from Walton. In Gibson (ed.) 1999, 141-50

Caseldine, A.E. 2000. The vegetation history of the Goldcliff Area. In M. Bell (ed.), Prehistoric Intertidal Archaeology in the Welsh Severn Estuary, 208-44. York: Council for British Archaeology Research Report 172

Caseldine, A.E. 2007. Plant macrofossil analysis. In A. Armour-Chelu, M. Bell, B. Brayshay, W.J. Britnell, N. Cameron, A.E. Caseldine, P.Q. Dresser, E. Francourt, S. Gonzalez, E. Healy, S. Johnson, J. Norris-Hill, R. Schulting \& D. Thomas, Shell middens and their environment at Prestatyn, north Wales, 295-296. In Bell (ed.) 2007c, 263-317

Caseldine, A.E. 2014. Pollen analysis at Craig y Dullfran and Banc Wernwgan and other recent palaeoenvironmental studies in Wales. Archaeologia Cambrensis 162, 275-307

Caseldine, A.E. \& Griffiths, C.J. 2004. Palaeo-environmental evidence from the Bronze Age house. In P. Crane, Excavations at Newton, Llanstadwell, Pembrokeshire, 9-10. Archaeology Wales 44, 3-31

Caseldine, A.E. \& Griffiths, C.J. 2006. The charred plant remains. In K. Murphy \& R.T.J. Evans (eds), Excavation of Neolithic pits, three ring-ditches and a palisaded enclosure at Cwm Meudwy, Llandysul, Ceredigion, 2003, 42-3. Archaeologia Cambrensis 155, 23-48

Caseldine, A.E., Griffiths, C.J. \& Peck, I. 2014. Charred plant remains. In G. Smith, A Late Bronze Age/Early Iron Age hilltop enclosure with evidence for Early and Middle Neolithic and Early Medieval settlement at Carrog, Llanbadrig, Anglesey, 76-81. Studia Celtica 48, $55-92$

Caseldine, A.E., Griffiths, C.J., Jones, S., Peck, I. \& Smith, G. 2016. A Late Post-Glacial environmental record and Early Neolithic intertidal peat land surface at Porth Neigwl, Llŷn Peninsula, Gwynedd. Studia Celtica 50, $1-18$

Caseldine, A.E., Griffiths, C.J., Roberts, J.G., Smith, G. \& Williams, J.L. 2017. Land use and environmental history of Waun Llanfair, an upland landscape above Penmaenmawr, North Wales. Archaeologia Cambrensis 166, 89-140

Chambers, F.M. 1982. Two radiocarbon-dated pollen diagrams from high-altitude blanket peats in south Wales. Journal of Ecology 70, 445-459

Chambers, F.M. \& Price, S.M. 1988. The environmental setting of Erw-wen and Moel y Gerddi: prehistoric enclosures in upland Ardudwy, North Wales. Proceedings of the Prehistoric Society 54, 93-100

Clapham, A. 2009. Plant macrofossil analysis. In A. Mann and D. Hurst, Buttington Cross, Welshpool, Powys, Wales. A Bronze Age Barrow and Post-Roman Grain Processing Site. Worcester: Historic Environment and Archaeology Service, Worcestershire County Council unpublished report 1714

Cobain, S. 2014. Plant macrofossils and charcoal. In J. Hart, I Wood, A. Barber, A. Brett \& A. Hardy, Prehistoric land use in the Clyst Valley: excavations at Hayes Farm, Clyst, Honiton, 1996-2012, 32-45. Proceedings of the Devon Archaeological Society 72, 1-56

Colledge, S. \& Conolly, J. (eds), 2007 The Origins and Spread of Domestic Plants in Southwest Asia and Europe. Walnut Creek CA: Left Coast Press

Colledge, S. \& Conolly, J. 2014. Wild plant use in European Neolithic subsistence economies: a formal assessment of preservation bias in archaeobotanical assemblages and the implications for understanding changes in plant diet breadth. Quaternary Science Reviews 101, 193-206

Colledge, S., Conolly, J. \& Shennan, S. 2005. The evolution of Neolithic farming from SW Asian origins to NW European limits. European Journal of Archaeology 8, 137-56

Cummings, V. \& Whittle, A. 2004. Places of Special Virtue: Megaliths in the Neolithic landscapes of Wales. Oxford: Oxbow Books

Dark, P. 2007. Plant communities and human activity in the lower submerged forest and on Mesolithic occupation sites. In Bell (ed.) 2007c, 169-87

Dark, P. \& Gent, H. 2001. Pests and diseases of prehistoric crops: a yield 'honeymoon' for early grain crops in Europe? Oxford Journal of Archaeology 20, 59-78

Davis, O. \& Sharples, N. 2017. Early Neolithic enclosures in Wales: a review of the evidence in light of recent discoveries at Caerau, Cardiff. Antiquaries Journal 97, 1-26

Deforce, K., Bastiaens, J., van Neer, W., Ervynck, A., Lentacker, A., Sergant, J. \& Crombé, P. 2013. Wood charcoal and seeds as indicators for animal husbandry in a wetland site during the Late Mesolithic-Early Neolithic transition period (Swifterbant culture, ca. 4600-4000 B.C.) in NW Belgium. Vegetation History and Archaeobotany 22, 51-60

Dudd, S.N., Evershed, R.P. \& Gibson, A.M. 1999. Evidence for varying patterns of exploitation of animal products in different prehistoric pottery traditions based on lipids preserved in surface and absorbed residues. Journal of Archaeological Science 26, 1473-82

Fairbairn, A.S. 2000. Charred seeds, fruits and tubers. In A. Whittle, J.J. Davies, I. Dennis, A.D. Fairbairn \& M.A. 


\section{E.R. Treasure et al. NEOLITHIC FARMING \& WILD PLANT EXPLOITATION, WALES}

Hamilton, Neolithic activity and occupation outside Windmill Hill causewayed enclosure, Wiltshire: survey and excavation 1992-3, 168-75. Wiltshire Archaeological \& Natural History Magazine 93, 131-80

Farquhar, G.D., Ehleringer, J.R. \& Hubick, K.T. 1989. Carbon isotope discrimination and photosynthesis. Annual Review of Plant Biology 40, 503-37

Ferrio, J.P., Araus, J.L., Buxó, R., Voltas, J., \& Bort, J. 2005. Water management practices and climate in ancient agriculture: inferences from the stable isotope composition of archaeobotanical remains. Vegetation History and Archaeobotany 14, 510-17

Fiorentino, G., Ferrio, J.P., Bogaard, A., Araus, J.L. \& Riehl, S. 2015. Stable isotopes in archaeobotanical research. Vegetation History and Archaeobotany 24, 215-27

Fraser, R.A., Bogaard, A., Heaton, T.H.E., Charles, M., Jones, G., Christensen, B.T., Halstead, P., Merbach, I., Poulton, P.R., Sparkes, D. \& Styring, A.K. 2011. Manuring and stable nitrogen isotope ratios in cereals and pulses: towards a new archaeobotanical approach to the inference of land use and dietary practices. Journal of Archaeological Science 38 (2),790-2804

Fyfe, R. 2007. The importance of local-scale openness within regions dominated by closed woodland. Journal of Quaternary Science 22, 571-78

Garrow, D., Griffiths, S., Anderson-Whymark, H. \& Sturt, F. 2017. Stepping stones to the Neolithic? Radiocarbon dating the Early Neolithic on islands within the 'western seaways' of Britain. Proceedings of the Prehistoric Society 83, 97-135

Gibson, A. (ed.) 1999. The Walton Basin Project: Excavation and survey in a prehistoric landscape 1993-7. York: Council for British Archaeology Research Report 118

Grant, F. 2008. Human impact and landscape change at Moel Llys y Coed in the Clwydian, Hills, North Wales: The Mesolithic - Present Day. Archaeology in Wales 48, 3-15

Griffiths, S. 2018. A cereal problem? What the current chronology of early cereal domesticates might tell us about changes in late fifth and early fourth millennium cal BC Ireland and Britain. Environmental Archaeology https:// doi.org/10.1080/14614103.2018.1529945

Gron, K.J., Gröcke, D.R., Larsson, M., Sørensen, L., Larsson, L., Rowley-Conwy, P.A. \& Church, M.J. 2017. Nitrogen isotope evidence for manuring of early Neolithic Funnel Beaker Culture cereals from Stensborg, Sweden. Journal of Archaeological Science Reports 14, $575-9$

Guttmann, E.B.A. 2005. Midden cultivation in prehistoric Britain: arable crops in gardens. World Archaeology 37, 224-39

Hall, V.A. 1989. A study of the modern pollen rain from a reconstructed 19th century farm. Irish Naturalists' Journal 23, 82-92

Halstead, P. 2006. Sheep in the garden: the integration of crop and livestock husbandry in early farming regimes of Greece and southern Europe. In D. Serjeanston \& D. Field (eds), Animals in the Neolithic of Britain and
Europe, 42-55. Oxford: Neolithic Studies Group Seminar Papers 7

Halstead, P. 2018. Forest clearance and land use by early farmers in Europe: insight from north Greek oral history. Quaternary International 496, 42-50

Halsted, J. 2007. Bronze Age Settlement in Shropshire: research potential and frameworks for settlement studies in the West Midlands. In P. Garwood (ed.), The Undiscovered Country: The earlier prehistory of the West Midlands, 166-81. Oxford: Oxbow Books

Hart, J., Rackham, J., Griffiths, S. \& Challinor, D. 2014. Burnt mounds along the Milford Haven to Brecon gas pipeline, 2006-07. Archaeologia Cambrensis 163, 133-72

Hather, J.G. \& Mason, S.L.R. 2002. Introduction: some issues in the archaeobotany of hunter-gatherers. In J.G. Hather \& S.L.R. Mason (eds), Hunter-gatherer Archaeobotany: Perspectives from the northern temperate zone, 1-14. London: University College London Institute of Archaeology

Hedges, R.E.M., Housley, R.A., Bronk Ramsey, C. \& van Klinken, G.J. 1993. Radiocarbon dates from the Oxford AMS system: Archaeometry datelist 16. Archaeometry 35, 147-67

Hillman, G. 1982. Appendix 6: charred remains of plants. In W.J. Britnell (ed.), The excavation of two round barrows at Trelystan, Powys, 198-200. Proceedings of the Prehistoric Society 48, 133-201

Hubbard, R.N.L.B. \& al Azm, A. 1999. Quantifying preservation and distortion in carbonized seeds; and investigating the history of friké production. Journal of Archaeological Science 17, 103-6

Huntley, J. 1996. The plant remains. In P. Abramson (ed.), Excavations along the Caythorpe gas pipeline, north Humberside, 80-1. Yorkshire Archaeology 68, 1-88

Innes, J., Blackford, J. \& Chambers, F. 2006. Kretzschmaria deusta and the northwest European mid-Holocene Ulmus decline at Moel y Gerddi, north Wales, United Kingdom. Palynology 30, 121-32

Jackson, R. \& Ray, K. 2012. Place, presencing and pits in the Neolithic of the Severn-Wye region. In Thomas \& Anderson-Whymark (eds) 2012, 145-70

Jacomet, S. 2007. Neolithic plant economies in the northern Alpine foreland from 5500-3500 cal BC. In Colledge \& Conolly (eds) 2007, 221-58

Jacomet, S., Ebersbach, R., Akeret, Ö., Antolín, F., Baum, T., Bogaard, A., Brombacher, C., Bleicher, N.K., HeitzWeniger, A., Hüster-Plogmann, H. \& Gross, E. 2016. On-site data cast doubts on the hypothesis of shifting cultivation in the late Neolithic (c. 4300-2400 cal. BC): Landscape management as an alternative paradigm. Holocene 26, 1858-74

Jones, G. 2000. Evaluating the importance of cultivation and collecting in Neolithic Britain. In A.S. Fairbairn (ed.), Plants in Neolithic Britain and Beyond, 79-84. Oxford: Neolithic Studies Group Seminar Papers 5

Jones, G. 2005. Garden cultivation of staple crops and its implications for settlement location and continuity. World Archaeology 37, 164-76 
Jones, G. \& Bogaard, A. 2017. Integration of cereal cultivation and animal husbandry in the British Neolithic: the evidence of charred plant remains from timber buildings at Lismore Fields. In P. Rowley-Conwy, D. Serjeantson \& P. Halstead (eds.) Economic Zooarchaeology: Studies in hunting, herding and early agriculture, 221-6. Oxford: Oxbow

Jones, G. \& Legge, A. 2008. Evaluating the role of cereal cultivation in the Neolithic: charred plant remains from Hambledon Hill. In R. Mercer \& R. Healy (eds.) Hambledon Hill, Dorset, England: Excavation and survey of a Neolithic monument complex and its surrounding landscape. Volume 2, 469-76. Swindon: English Heritage

Jones, G. \& Rowley-Conwy, P.A. 2007. On the importance of cereal cultivation in the British Neolithic. In Colledge \& Conolly (eds) 2007, 391-420

Jones, N.W. 2009. Womaston Neolithic causewayed enclosure, Powys: survey and excavation 2008. Archaeologia Cambrensis 158, 19-42

Jones, N.W. 2012. The Hindwell Cursus Radnorshire. Excavation and geopybsical survey 2011. Welshpool: Clwyd-Powys Archaeological Trust unpublished Report 1114

Jones, N.W. \& Gibson, A.M. 2017. Neolithic palisaded enclosures of Radnorshire's Walton Basin. Archaeologia Cambrensis 166, 33-88

Kanstrup, M., Holst, M.K., Jensen, P.M., Thomsen, I.K. \& Christensen, B.T. 2014. Searching for long-term trends in prehistoric manuring practice. $\delta^{15} \mathrm{~N}$ analyses of charred cereal grains from the 4 th to the 1 st millennium BC. Journal of Archaeological Science 51, 115-25

Kenney, J. 2008 Recent excavations at Parc Bryn Cegin, Llandygai, near Bangor, North Wales. Archaeologia Cambrensis 157, 9-142

Kenney, J. 2012 Burnt mounds in north-west Wales: are these ubiquitous features really so dull? In W.J. Britnell \& R.J. Silvester (eds.) Reflections on the Past: Essays in honour of Frances Lynch, 254-79. Welshpool: Cambrian Archaeological Association

Kenney, J., McGuinness, N., Cooke, R., Rees, C. \& Davidson, A. 2011. Parc Cybi, Holyhead: Post-excavation assessment of potential report. Volume 1. Bangor: Gwynedd Archaeological Trust unpublished Report 954

Kirleis, W. \& Fischer, E. 2014. Neolithic cultivation of tetraploid free threshing wheat in Denmark and Northern Germany: implications for crop diversity and societal dynamics of the Funnel Beaker Culture. Vegetation History Archaeobotany 23, 81-96

Kirleis, W., Klooß, S., Kroll, H. \& Müller, J. 2012. Crop growing and gathering in the northern German Neolithic: a review supplemented by new results. Vegetation History and Archaeobotany 21, 221-42

Kohler-Schneider, M. 2007. Early agriculture and subsistence in Austria: a review of Neolithic plant records. In Colledge \& Conolly (eds) 2007, 209-20

Kreuz, A. 2007. Archaeobotanical perspectives on the beginning of agriculture north of the Alps. In Colledge \& Conolly (eds) 2007, 259-94

Kubiak-Martens, L. 2002. New evidence for the use of root foods in pre-agrarian subsistence recovered from the late
Mesolithic site at Halsskov, Denmark. Vegetation History and Archaeobotany 11, 23-32

Legge, A.J. 1989. Milking the evidence: a reply to Entwistle and Grant. In A. Milles, D. Willimans \& N. Gardiner (eds), The Beginnings of Agriculture, 217-42. Oxford: British Archaeological Report S496

Lightfoot, E. \& Stevens, R.E. 2012. Stable isotope investigations of charred barley (Hordeum vulgare) and wheat (Triticum spelta) grains from Danebury Hillfort: implications for palaeodietary reconstructions. Journal of Archaeological Science 39, 656-62

Lynch, F. 2000. Prehistoric Wales. Stroud: Tempus

McClatchie, M., Bogaard, A., Colledge, S., Whitehouse, N., Schulting, R.J., Barratt, P. \& McLaughlin, T.R. 2014. Neolithic farming in north-western Europe: archaeobotanical evidence from Ireland. Journal of Archaeological Science 51, 206-15

McClatchie, M., Bogaard, A., Colledge, S., Whitehouse, N., Schulting, R.J., Barratt, P. \& McLaughlin, T.R. 2016. Farming and foraging in Neolithic Ireland: an archaeobotanical perspective. Antiquity 90, 302-18

McKenna, R. 2013. Appendix III.7. An assessment of the palaeoenvironmental potential. In J. Kenney \& L.W. Parry. Ysgol yr Hendre, Llanbeblig, Caernarfon: Report on archaeological excavations. Bangor: Gwynedd Archaeological Trsut unpublished Report 1103

McKenna, R. 2014. Palaeobotanical evidence. In G. Smith \& E. Walker, Snail Cave rock shelter, North Wales: a new prehistoric site, 120-21. Archaeologia Cambrensis 163, 99-131

McLaughlin, T.R., Whitehouse, N.J., Schulting, R.J., McClatchie, M., Barratt, P. \& Bogaard, A. 2016. The changing face of Neolithic and Bronze Age Ireland: A big data approach to the settlement and burial records. Journal of World Prehistory 29, 117-53

Meylemans, E., Bastiaens, J., Boudin, M., Defore, K., Ervynck, A., Perdaen, Y., Sergant, J., Storme, A. \& Crombé, P. 2018. The oldest cereals in the coversand area along the North Sea coast of NW Europe, between ca. 4800 and $3500 \mathrm{cal} \mathrm{BC}$, at the wetland site of 'BazelSluis' (Belgium). Journal of Anthropological Archaeology 49, 1-7

Mighall, T.M. \& Chambers, F.M. 1995. Holocene vegetation history and human impact at Bryn y Castell, Snowdonia, north Wales. New Phytologist 130, 299-321

Moffett, L., Robinson, A. \& Straker, V. 1989. Cereals, fruit and nuts: charred plant remains from Neolithic sites in England and Wales and the Neolithic economy. In A. Milles, D. Willimans \& N. Gardiner (eds), The Beginnings of Agriculture, 243-61. Oxford: British Archaeological Report S496

Murphy, K., Caseldine, A.E., Barker, L., Fielding, S., Burrow, S. \& Carlsen, S. 2015. Mesolithic human and animal footprints at Lydstep Haven, Pembrokeshire, 2010: the environmental context. Archaeologia Cambrensis 163, 23-41

Nayling, N. \& Caseldine, A.E. 1997. Excavations at Caldicot, Gwent: Bronze Age palaeochannels in the lower Nedern valley. York: Council for British Archaeology Research Report 108 


\section{E.R. Treasure et al. NEOLITHIC FARMING \& WILD PLANT EXPLOITATION, WALES}

Neil, S., Evans, J., Montgomery, J. \& Scarre, C. 2016. Isotopic evidence for residential mobility of farming communities during the transition to agriculture in Britain. Royal Society Open Science 3, 150522

Neil, S., Montgomery, J., Evans, J., Cook, G.T. \& Scarre, C. 2017. Land use and mobility during the Neolithic in Wales explored using isotope analysis of tooth enamel. American Journal of Physical Anthropology 164, 371-93

Nitsch, E.K., Charles, M. \& Bogaard, A. 2014. Calculating a statistically robust $\delta^{13} \mathrm{C}$ and $\delta^{15} \mathrm{~N}$ offset for charred cereal and pulse seeds. STAR 1, 1-8

Out, W.A. 2012. What's in a hearth? Seeds and fruits from the Neolithic fishing and fowling camp at Bergschenhoek, the Netherlands, in a wider context. Vegetation History and Archaeobotany 21, 201-14

Parker, A.G., Goudie, A.S., Anderson, D.E., Robinson, M.A. \& Bonsall, C. 2002. A review of the mid-Holocene elm decline in the British Isles. Progress in Physical Geography 26, 1-45

Pelling, R. \& Campbell, G. 2013. Plant resources. In M. Canti, G. Campbell \& S. Gearey (eds), Stonehenge World Heritage Site Synthesis: Prehistoric landscape, environment and economy, 37-60. Swindon: English Heritage Research Department Report Series 43/2013

Pelling, R., Campbell, G., Carruthers, W., Hunter, K. \& Marshall, P. 2015. Exploring contamination (intrusion and residuality) in the archaeobotanical record: case studies from central and southern England. Vegetation History and Archaeobotany 24, 85-99

Peterson, R. 2004. Away from the numbers: diversity and invisibility in Neolithic Wales. In V. Cummings \& C. Fowler (eds), The Neolithic of the Irish Sea: Materiality and traditions of practice, 191-201. Oxford: Oxbow Books

Rackham, J. 2013a. The palaeoenvironmental evidence. In J. Hart, South Wales Gas Pipeline Project Sites 24.06 and 24.07. Land North-East of Gurrey Cottage, Llandeilo, Carmarthenshire. Archaeological Excavation. Cirencester: Cotswold Archaeology unpublished Report 13274

Rackham, J. 2013b. Palaeoenvironmental evidence. In J. Hart, S. Joyce \& C. Leonard, South Wales Gas Pipeline Project. Site 501. Land South-West of Llwyn, Llangain, Carmarthenshire. Archaeological Excavation. Cirencester: Cotswold Archaeology unpublished Report 13246

Rackham, J. 2014. The palaeoenvironmental evidence. In A. Barber \& J. Hart 2014

Rackham, J. 2015. The palaeoenvironmental evidence. In A. Barber \& J. Hart. South Wales gas pipeline project. Site 503. Land east of Vaynor Farm, Llanddowror, Camarthenshire. Archaeological Excavation. Cirencester: Cotswold Archaeology, unpublished Report 9150

Ray, K. \& Thomas, J. 2018. Neolithic Britain: The transformation of social worlds. Oxford: Oxford University Press

Rees, C. \& Jones, M. 2015. Neolithic houses from Llanfaethlu, Anglesey. PAST 81, 1-3

Robinson, D.E. 2007. Exploitation of plant resources in the Mesolithic and Neolithic of southern Scandinavia: from gathering to harvesting. In Colledge \& Conolly (eds) 2007, 359-74

Robinson, M. 2000. Further consideration of Neolithic charred cereals, fruits and nuts. In A.S. Fairbairn (ed.), Plants in Neolithic Britain and Beyond, 85-90. Oxford: Neolithic Studies Group Seminar Papers 5

Rösch, M., Biester, H., Bogenrieder, A., Eckmeier, E., Ehrmann, O., Gerlach, R., Hall, M., Hartkopf-Fröder, C., Herrmann, L., Kury, B. \& Lechterbeck, J. 2017. Late Neolithic agriculture in temperate Europe - a longterm experimental approach. Land 6, 11-28

Rösch, M., Kleinmann, A., Lechterbeck, J. \& Wick, L. 2014. Botanical off-site and on-site data as indicators of different land use systems: a discussion with examples from Southwest Germany. Vegetation History and Archaeobotany 23, 121-33

Rowley-Conwy, P.A. 2004. How the west was lost: a reconsideration of agricultural origins in Britain, Ireland and southern Scandinavia. Current Anthropology 45, 83-113

Rowley-Conwy, P.A. 2011. Westward Ho! The spread of agriculture from Central Europe to the Atlantic. Current Anthropology 52, 431-51

Rowley-Conwy, P.A. \& Layton, B. 2011. Foraging and farming as niche construction: stable and unstable adaptions. Philosophical Transactions of the Royal Society B 366, 849-62

Rowley-Conwy P.A. \& Legge, A. 2015. Subsistence practices in western and northern Europe. In C. Fowler, J. Harding \& D. Hofmann (eds), The Oxford Handbook of Neolithic Europe, 429-46. Oxford: Oxford University Press

Salavert, A. 2011. Plant economy of the first farmers of central Belgium (Linearbandkeramik, 5200-5000 B.C.). Vegetation History and Archaeobotany 20, 321-32

Schmidl, A., Carrott, J. \& Jaques, D. 2008. Appendix XIV: The biological remains. In J. Kenney, Recent Excavations at Llandygai, near Bangor, North Wales. Volume III: appendices, 122-82. Bangor: Gwynedd Archaeological Trust unpublished Report 764.

Schulting, R.J. 2008. Foodways and social ecologies from the Early Mesolithic to Early Bronze Age. In J. Pollard (ed.), Prehistoric Britain, 90-120. Oxford: Blackwell

Schulting, R.J. \& Whittle, A. 2003. Construction and primary use of chambered tombs in England, Wales and Scotland, 73-6. In C. Scarre, P. Arias, B. Burenhult B, M. Fano, I, Oosterbeek, R.J. Schulting, A. Sheridan \& A. Whittle. Megalithic chronologies. In G. Burenhult \& S. Westergaard (eds) Stone and Bones. Formal disposal of the dead in Atlantic Europe during the MesolithicNeolithic interface 6000-3000 BC, 65-111. Oxford: British Archaeological Report S1201

Schulting, R.J., Fibiger, L., Macphail, R., McLaughlin, R., Murray, E., Price, C. \& Walker, E.A. 2013. Mesolithic and Neolithic human remains from Foxhole Cave, Gower, South Wales. Antiquaries Journal 93, 1-23

Sheridan, A. 2007. From Picardie to Pickering and Pencraig Hill? New information on the 'carinated bowl Neolithic' in northern Britain. In Whittle \& Cummings (eds) 2007, $441-92$ 
Sheridan, A. 2010. The Neolithization of Britain and Ireland: the big picture. In B. Finlayson \& G. Warren (eds), Landscapes in Transition, 89-105. Oxford: Council for British Research in the Levant Supplementary Series 8

Sievers, C. \& Wadley, L. 2008. Going underground: experimental carbonization of fruiting structures under hearths. Journal of Archaeological Science 35, 2909-17

Smith, B.D. 2011. General patterns of niche construction and the management of 'wild' plant and animal resources by small-scale pre-industrial societies. Philosophical Transactions of the Royal Society Series B 366, 836-48

Smith, G.H., Caseldine, A.E., Griffiths, C.J., Peck, I., Nayling, N. \& Jenkins, D. 2017. An Early Bronze Age burnt mound trough and boat fragment with accompanying palaeobotanical and pollen analysis at Nant Farm, Porth Neigwl, Llŷn Peninsula, Gwynedd. Studia Celtica 51, 1-63

Smyth, J. 2014. Settlement in the Irish Neolithic: New discoveries at the edge of Europe. Oxford: Prehistoric Society Research Papers 8

Sørensen, L. \& Karg, S. 2014. The expansion of agrarian societies towards the north - new evidence for agriculture during the Mesolithic/Neolithic transition in southern Scandinavia. Journal of Archaeological Science 51, 98-114

Stace, C. 2010. New Flora of the British Isles. Cambridge: Cambridge University Press

Stevens, C.J. 2007. Reconsidering the evidence: towards an understanding of the social contexts of subsistence production in Neolithic Britain. In Colledge \& Conolly (eds), 375-90

Stevens, C.J. \& Fuller, D.Q 2012. Did Neolithic farming fail? The case for a Bronze Age agricultural revolution in the British Isles. Antiquity 86, 707-22

Stevens, C.J. \& Fuller, D.Q. 2015. Alternative strategies to agriculture: the evidence for climatic shocks and cereal declines during the British Neolithic and Bronze Age (a reply to Bishop). World Archaeology 47, 856-75

Stevens, C.J. \& Fuller, D.Q. 2018. The fighting flora: an examination of the origins and changing composition of the weed flora of the British Isles. In E. Lightfoot, X. Liu and D.Q. Fuller (eds), Far from the Hearth: Essays in honour of Martin K. Jones, 23-36. Cambridge: McDonald Institute for Archaeological Research

Stevens, R.E., Lightfoot, E., Allen, T. \& Hedges, R.E.M. 2012. Palaeodiet at Eton College Rowing Course, Buckinghamshire: isotopic changes in human diet in the Neolithic, Bronze Age, Iron Age and Roman periods throughout the British Isles. Archaeological and Anthropological Science 4, 167-84

Straker, V. 1990. Carbonised plant macrofossils. In A. Saville, Hazelton North, Gloucestershire, 1979-82: The excavation of a Neolithic long cairn of the CotswoldSevern group, 214-18. London: English Heritage

Styring, A.K., Maier, U., Stephan, E., Schlichtherle, H. \& Bogaard, A. 2016. Cultivation of choice: new insights into farming practices at Neolithic lakeshore sites. Antiquity 90, 95-110

Styring, A.K., Rösch, M, Stephan, E., Stika, H-P, Fischer, E., Sillmann, M. \& Bogaard, A. 2017. Centralisation and long-term change in farming regimes: comparing agricultural practices in Neolithic and Iron Age south-west Germany. Proceedings of the Prehistoric Society 83, 357-81

Szpak, P. 2014. Complexities of nitrogen isotope biogeochemistry in plant-soil systems: implications for the study of ancient agricultural and animal management practices. Frontiers in Plant Science 5, 288

Thomas, J. 2003. Thoughts on the 'Repacked' Neolithic revolution. Antiquity 77, 67-74

Thomas, J. 2004. Current debates on the MesolithicNeolithic transition in Britain and Ireland. Documenta Praehistorica 31, 113-30

Thomas, J. 2007. Mesolithic-Neolithic transitions in Britain: from essence to inhabitation. In Whittle \& Cummings (eds) 2007, 423-40

Thomas J. 2014. The Birth of Neolithic Britain: An interpretative account. Oxford: Oxford University Press

Treasure, E.R. \& Church, M.J. 2017. Can't find a pulse? Celtic bean (Vicia faba L.) in British prehistory. Environmental Archaeology 22, 113-27

Treasure, E.R., Church, M.J. \& Gröcke, D.R. 2016. The influence of manuring on stable isotopes $\left(\delta^{13} \mathrm{C}\right.$ and $\delta^{15} \mathrm{~N}$ ) in Celtic bean (Vicia faba L.): archaeobotanical and palaeodietary implications. Archaeological and Anthropological Sciences 8, 555-62

Walker, M., Jones, S., Hussey, R. \& Buckley, S. 2006. Mesolithic burning in the Welsh uplands: evidence from Esgair Ffraith, near Lampeter, west Wales. Archaeology in Wales 46, 3-10

Wallace, M., Jones, G., Charles, M., Fraser, R., Halstead, P., Heaton, T.H.E. \& Bogaard, A. 2013. Stable carbon isotope analysis as a direct means of inferring crop water status and water management practices. World Archaeology 3, 388-409

Warden, L., Moros, M., Neumann, T., Shennan, S., Timpson, A., Manning, K., Sollai, M., Wacker, L., Perner, K., Häusler, K. \& Leipe, T. 2017. Climate induced human demographic and cultural change in northern Europe during the mid-Holocene. Scientific Reports 7, 15251

Warren, G., Davis, S., McClatchie, M. \& Sands, R. 2014. The potential role of humans in structuring the wooded landscapes of Mesolithic Ireland: a review of data and discussions of approaches. Vegetation History and Archaeobotany 23, 629-46

Watkins, R., Scourse, J.D. \& Allen, J.R.M. 2007. The Holocene vegetation history of the Arfon Platform, north Wales, UK. Boreas 36, 170-81

Whitehouse, N.J. \& Kirleis, W. 2014. The world reshaped: Practices and impacts of early agrarian societies. Journal of Archaeological Science 51, 1-11

Whitehouse, N.J. \& Smith, D 2010. How fragmented was the British Holocene wildwood? Perspective on the 'Vera' grazing debate from the fossil beetle record. Quaternary Science Reviews 29, 539-53

Whitehouse, N.J., Schulting, R.J., McClatchie, M., Barratt, P., McLaughlin, T.R., Bogaard, A., Colledge, S., Marchant, R., Gaffrey, J \& Bunting, M.J. 2014. 


\section{E.R. Treasure et al. NEOLITHIC FARMING \& WILD PLANT EXPLOITATION, WALES}

Neolithic agriculture on the European western frontier: the boom and bust of early farming in Ireland. Journal of Archaeological Science 51, 181-205

Whittle, A. \& Bickle, P. (eds). 2014. Early Farmers: The view from archaeology and science. Oxford: Proceedings of the British Academy 198

Whittle A. \& Cummings, V. (eds). 2007. Going over the Mesolithic-Neolithic Transition in north-west Europe. Oxford: Proceedings of the British Academy 144

Whittle, A., Healy, F. \& Bayliss, A. 2011. Gathering Time: Dating the Early Neolithic enclosures of southern Britain and Ireland. Oxford: Oxbow Books

Wilkinson, T.J., Murphy, P.L., Brown, N. \& Heppell, E.M. 2012. The Archaeology of the Essex Coast, Volume II: Excavations at the prehistoric site of the Stumble. Chelmsford: East Anglian Archaeology Report 144

Williams, D. 1999. Plant macrofossils. In S.I. White \& G. Smith, A funerary and ceremonial centre at Capel
Eithin, Gaerwen, Anglesey: excavations of Neolithic, Bronze Age, Roman and early medieval features in 1980 and 1981, 109-12. Transactions of the Anglesey Antiquarian Society 1999, 1-179

Woodbridge, J. Fyfe, R., Law, B. \& Haworth-Johns, A. 2012. A spatial approach to upland vegetation change and human impact: the Aber Valley, Snowdonia. Environmental Archaeology 17, 80-94

Worley, F., Madgwick, R., Pelling, R., Marshall, P., Evans, J.A., Lamb, A.L., López-Dóriga, I.L., Ramsey, C.B., Dunbar, E., Reimer, P. \& Vallender, J. 2019. Understanding Middle Neolithic food and farming in and around the Stonehenge World Heritage Site: An integrated approach. Journal of Archaeological Science: Reports 26, 101838

Zvelebil, M. 1994. Plant use in the Mesolithic and its role in the transition to farming. Proceedings of the Prehistoric Society $60,35-74$

\section{RÉSUMÉ}

Agriculture Néolithique et exploitation des plantes sauvages dans l'ouest de la Grande-Bretagne : témoignages archéobotaniqques et d'isotopes stables de récoltes du Pays de Galles (env. 4000-2200 cal av. J.-C.), de Edward R. Treasure, Darren R. Gröcke, Astrid E. Caseldine et Mike J. Church

L'introduction de l'agriculture est un élément clef déterminant du néolithique, toutefois, un considérable débat persiste en ce qui concerne la nature et l'importance des premières pratiques agricoles dans le nord-ouest de l'Europe. Cette étude révise les témoignages archéobotaniques de 95 sites néolithiques (env. 4000-2200 cal av. J.-C.), au Pays de Galles se concentrant sur l'exploitation des plantes sauvages, la gamme de cultures sprésentes et l'importance des céréales dans les pratiques de subsistance. Les pratiques de culture des céréales du début du néolithique au Pays de Galles sont aussi examinées au moyen d'une analyse des isotopes stables de graines de céréales carbone $\left(\delta^{13} \mathrm{C}\right)$ et nitrogène $\left(\delta^{15} \mathrm{~N}\right)$. La période du début du néolithique a vu une large diffusion de la culture de céréales parallèlement à de considérables témoignages de la continuation de l'exploitation des plantes sauvages, en particulier les noisettes et les fruits sauvages. La possibilité que des plantes sauvages et des bois étaient délibérément controlés ou modifiés pour promouvoir la croissance de certaines plantes est soulignée. De petits assemblages de graines de céréales, avec peu d'évidence de menue paille ou de graines de mauvaises herbes sont courants au début du néolithique tandis que les sites riches en céréales sont rares. L'épeautre était la culture dominante au début du néolithique alors que d'autres types de céréales étaient enregistrés en petites quantités. Les valeurs de l'isotope de nitrogène $\left(\delta^{15} \mathrm{~N}\right)$ de céréales des sites du début du néolithique ne rapportèrent que peu de témoignages de fumure intensive. Nous suggérons qu'il se pourrait que les conditions de culture aient été moins intensives si, on les compare à celles d'autres régions de Grande-Bretagne ou d'Europe. A la période du néolithique plus tardif, il existe des témoignages d'un décllin de l'importance des céréales. Finalement les données archéobotaniques et d'isotopes de cultures de cette étude sont éenvisagées dans le contexte plus étendu de l'Europe.

\section{ZUSSAMENFASSUNG}

Neolithische Landwirtschaft und die Nutzung von Wildpflanzen im Westen Großbritanniens: Archäobotanische Daten und stabile Isotopen von Kulturpflanzen aus Wales (ca. 4000-2200 cal BC), von Edward R. Treasure, Darren R. Gröcke, Astrid E. Caseldine und Mike J. Church

Die Einführung des Ackerbaus ist ein entscheidendes Bestimmungselement des Neolithikums, doch über den Charakter und die Bedeutung früher landwirtschaftlicher Aktivitäten in Nordwesteuropa besteht weiterhin eine große Uneinigkeit. Dieser Beitrag evaluiert die archäobotanischen Daten von 95 neolithischen Fundplätzen (ca. 4000-2200 cal BC) in Wales und konzentriert sich dabei auf die Nutzung von Wildpflanzen, die Arten 
überlieferter Kulturpflanzen und die Bedeutung von Getreide bei den Subsistenzpraktiken. Die Methoden des Anbaus von Getreide im frühneolithischen Wales werden anhand von Analysen stabiler Kohlenstoff- $\left(\delta^{13} \mathrm{C}\right)$ und Stickstoffisotopen $\left(\delta^{15} \mathrm{~N}\right)$ ebenfalls untersucht. Im frühen Neolithikum wurden Getreide weithin übernommen, während zugleich zahlreiche Daten auf die fortbestehende Nutzung von Wildpflanzen hinweisen, vor allem Haselnüssen und wilden Früchten. Die Möglichkeit wird erörtert, dass wilde Pflanzen und Wälder bewusst gepflegt oder umgeformt wurden, um das Wachstum bestimmter Pflanzen zu fördern. Im frühen Neolithikum treten kleine Mengen an Getreidekörnern weitgehend ohne Spreu oder Unkrautsaaten recht häufig auf, während Fundplätze mit reichen Getreidefunden selten sind. Emmer war im Frühneolithikum die wichtigste Nutzpflanze, weitere Getreidearten wurden in kleinen Mengen festgestellt. Stickstoffisotopenwerte $\left(\delta^{15} \mathrm{~N}\right)$ von Getreiden von frühneolithischen Plätzen liefern kaum Hinweise auf intensive Düngung. Wir schließen daraus, dass die Art des Anbaus weniger intensiv war als in anderen Regionen Großbritanniens und Europas. Für das spätere Neolithikum weisen die Daten auf einen Rückgang der Bedeutung von Getreide hin. Abschließend werden die archäobotanischen Daten und die Daten der Isotopenanalysen von Nutzpflanzen dieser Studie in ihrem weiteren europäischen Kontexts erörtert.

Agricultura neolitica y explotación de plantas silvestres en el oeste de Gran Bretaña: evidencia arqueobotánica e isótopos estables de cultivos de Gales (c. 4000-2200 cal BC), por Edward R. Treasure, Darren R. Gröcke, Astrid E. Caseldine y Mike J. Church

La introducción de la agricultura es un elemento definitorio del Neolítico, aunque persiste un considerable debate en relación a la naturaleza y el significado de las primeras prácticas agrícolas en el noroeste de Europa. Este artículo revisa la evidencia arqueobotánica de 95 yacimientos neolíticos (c. 4000-2200 cal BC) en Gales, centrándose en la explotación de plantas silvestres, el rango de cereales presentes y su significación en las prácticas de subsistencia. Se revisan las prácticas de cultivo de los cereales en el Neolítico inicial de Gales a través del análisis de isótopos estables de carbono $\left(\delta^{13} \mathrm{C}\right)$ y el nitrógeno $\left(\delta^{15} \mathrm{~N}\right)$. El Neolítico inicial fue testigo de la introducción generalizada de cereales al mismo tiempo que se documenta una explotación continua de plantas silvestres, especialmente avellanas y frutos silvestres. Se resalta la posibilidad de que las plantas silvestres y los bosques fueran deliberadamente gestionados o alterados para favorecer el crecimiento de ciertas plantas. Los pequeños conjuntos de grano de cereal, con poca evidencia de cascarillas y semillas de malas hierbas, son comunes en el Neolítico inicial, mientras que los sitios ricos en cereales son escasos. El trigo vestido o farro fue el cultivo dominante durante el Neolítico inicial, mientras que otros tipos de cereales son registrados en pequeñas cantidades. Los valores de nitrógeno $\left(\delta^{15} \mathrm{~N}\right)$ de los cereales de los yacimientos del Neolítico inicial aportan poca evidencia sobre una fertilización intensiva. Se propone que las condiciones de cultivo podrían haber sido menos intensivas que las producidas en otras áreas de Gran Bretaña y Europa. En el Neolítico final, la evidencia arqueológica refleja un declive de la importancia de los cereales. Finalmente, los datos arqueobotánicos y la evidencia isotópica presentada en este estudio se compara con un contexto europeo más amplio. 